Contract No. W-7405-eng-26

METALIURGY DIVISION

SPECIFICATIONS FOR FUEL ASSEMBLIES FOR CORE I OF THE EXPERTMENTAI GAS-COOLED REACTOR

DATE ISSUED

December 9, 1960

OAK RIDGE NATIONAI LABORATORY

Oak Ridge, Tennessee operated by

UNION CARBIDE CORPORATION

for the

U: S. ATOMIC ENERGY COMMISSION 


\section{DISCLAIMER}

This report was prepared as an account of work sponsored by an agency of the United States Government. Neither the United States Government nor any agency Thereof, nor any of their employees, makes any warranty, express or implied, or assumes any legal liability or responsibility for the accuracy, completeness, or usefulness of any information, apparatus, product, or process disclosed, or represents that its use would not infringe privately owned rights. Reference herein to any specific commercial product, process, or service by trade name, trademark, manufacturer, or otherwise does not necessarily constitute or imply its endorsement, recommendation, or favoring by the United States Government or any agency thereof. The views and opinions of authors expressed herein do not necessarily state or reflect those of the United States Government or any agency thereof. 


\section{DISCLAIMER}

Portions of this document may be illegible in electronic image products. Images are produced from the best available original document. 
CONTENTS

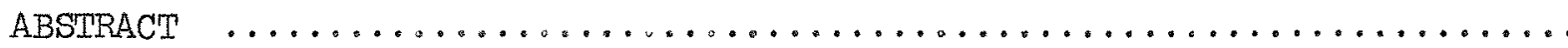

Master Specification for Fuel Assembly for Core I of the Expertmental Gas-Cooled Reactor, Spec. No. EGCR-2

Specification for Fuel Elements for Core I Fuel Assemblies for the

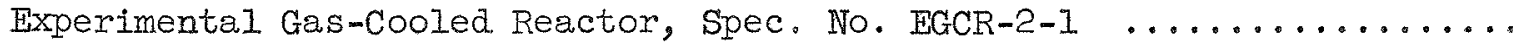

Specification for Fuel Element Tubes for Core I Fuel Assemblies for the Experimental Gas-Cooled Reactor, Spec. No. EGCR-2-1-1

Specification for Top and Bottom End Caps for Core I Fuel Assemblies for the ExperimentaI Gas-Cooled Reactor, Spec. No. EGCR-2-I-2 ........

Specification for Uranium Dioxide Fuel Pellets for Core I Fuel Assemblies for the Experimental Gas-Cooled Reactor, Spec. No. EGCR-2-1-3 Specification for Magnesium Oxide Pellets for Core I Fuel Assemblies for the Experimental GasmCooled Reactor, Spec. No. EGCR-2-1-4 ........

Specification for Fuel Element Spacers for Core I Fuel Assemblies for the Experimental Gas-Cooled Reactor, Spec. No. EGCR-2-1-5

Specification for Top Spiders and Lower Spiders for Core I Fuel Assemblies for the Experimental Gas-Cooled. Reactor, Spec. No. EGCR-2-2

Specification for Graphite Support Sleeves for Core I Fuel Assemblies for the Experimental Gas-Cooled Reactor, Spec. No. EGCR-2-3

Specification for Records to be Kept on Core I Fuel Assemblies for the Experimental Gas-Cooled Reactor, Spec. No. EGCR-2-4 


\title{
SPECIFICATIONS FOR FUEL ASSEMBLIES FOR CORE I OF THE EXPERIMENTAL GAS-COOLED REACTOR
}

\author{
J. H. Coobs \\ E. A. Wick* \\ R. M. Evans
}

\begin{abstract}
These specifications for the fuel assemblies for Core I of the Experimental Gas-Cooled Reactor (EGCR) have been developed for use in procuring the first core loading. A fuel assembly for the EGCR consists of a cluster of seven cylindrical fuel elements spaced and supported within a graphite sleeve. Each fuel element consists of a stainless steel tube containing a column of hollow $\mathrm{UO}_{2}$ pellets and having a spacer brazed at the midsection to control the spacing between fuel elements in a cluster. A master specification for the fuel assembly, a supplementary specification for each of the components, and a specification on record keeping during manufacture are included.
\end{abstract}

*Allis-Chalmers Manufacturing Company, Nuclear Power Department, Washington, D. C. 


\section{SPECIFICATIONS FOR FUEI ASSEMBLIES FOR CORE I OF THE EXPERIMENTAI GAS-COOLED REACTOR}

\section{INTRODUCTION}

The Experimental Gas Cooled Feactor (EGCR) is a combined experimental and power demonstration reactor now under construction at Oak Ridge, Tennessee, and scheduled for operation in late 1962. It is fueled with enriched uranium dioxide, clad in siainiess steel, moderated with graphite, and cooled with helium. The plant is designed to produce $84.3 \mathrm{Mw}(\mathrm{m})$ and $22 \mathrm{Mw}(\mathrm{E})$ with the reactor coolm ant outlet temperature of $1050^{\circ} \mathrm{F}$.

The reactor portion of the plant consists of a pressure vessel which con tains a temperature barrier, a graphite core, fuel assemblies, and control rods. The reactor power of $84.3 \mathrm{Mw}(\mathrm{T})$ is extracted by a belium flow of $427000 \mathrm{lb} / \mathrm{hr}$ at 315 psia. The coolant enters the reactor at $510^{\circ} \mathrm{F}$ and exits at $1050^{\circ} \mathrm{F}$.

The core is a vertical cylinder constructed of monolitbic columns of graphite. Vertical channels are provided through the graphite for the fuel assemblies, control rods, experimental loops, and fiux plotters.

A fuel assembly consists of a cluster of seven cylindrical stainless steel tubes spaced and supported within a graphite sleeve. A stack of six assemblies plus one dummy each at the top and bottom fill a fuel channel. Zone loading will be used for core startup, wh one half the fuel assemblies containing approx $2.2 \%$ enriched $\mathrm{UO}_{2}$ pellets and one half containing $2.4 \%$ enriched pellets. The enrichment of the feed fuel assemblies is approx 2.6\%。

The reactor is designed for fuel charging and discharging under load. These fuel-handling operations are accomplished by a charge machine located beneath the reactor and a service machine located above the reactor. The charge machine is used for normal loading and unloading of reactor fuel assemblies. The service machine was designed to handle control rod assemblies, flux-plotting devices, fuel assemblies, special fuel assemblies, and other special devices.

The specifications are intended to define the product and are not intended. to define the manufacturing process or procedures, except in a few instances where the quality of the product cannot be controljed by a product specification alone.

A master specification for the fuel assembly, a supplementary specification for each component, and a record keeping specification are included. These define the fuel assembly in detail and should enable the seller to solicit bids from seller's subcontractors by merely extracting the required component specification and forwarding it to the subcontractor.

The specification for $\mathrm{UO}_{2}$ fuel pellets is written so that the pellets are in specified stack lengths and weights; the stacks are loaded into the fuel element tubes and shipped or moved to the location where the final closure weld is made. While this arrangement appears to offer an economical advantage, it is merely a suggestion and is not a requirement. 
EGCR FUEL ASSEMBLY SPECIFICATION

METALLURGY DIVISION

OAK RIDGE NATIONAL IABORATORY

Union Carbide Nuclear Company

A Division of Union Carbide Corporation

Oak Ridge, Tennessee
Spec. No. EGCR-2

Date: Hov. I, 1960

Page: 1 of 6

\section{Subject: MASTER SPECIFICATION FOR FUEL ASSEMBLY FOR CORE I OF THE EXPERIMENTAL GAS-COOLED REACTOR}

\section{SCOPE:}

This specification defines the fuel assembly which consists of a cluster of seven cylindrical stainless steel fuel elements positioned inside a graphite support sleeve. The fuel elements are loaded with cored $\mathrm{JO}_{2}$ pellets. Three enrichments of $\mathrm{UO}_{2}$ varying from $2.2 \%$ to $2.6 \%$ $\mathrm{U}^{235}$ are included, with each fuel assembly containing pellets of only one enrichment. A top and lower spider are used to position the fuel elements inside the graphite sleeve.

II. MANUFACTURIING REQUIREMENTS:

The fuel assemblies shall be manufactured in accordance with Dwg. D-202-054-9822-D, "Fuel Assembly, Fuel. Element, and Support Sleeve" and in accordance with this specification.

The seller shall qualify his procedure for welding fuel elements to top spiders as described in section XI-A of this specification. AII fuel element-to-spider welds shall be made by this procedure.

III. REFERENCES:

A. Specifications

1. EGCR-2-1, "Specification for Fuel Elements for Core I Fuel Assemblies for the Experimental Gas-Cooled. Reactor"

2. EGCR-2-2, "Specification for Top Spiders and Lower Spiders for Core I Fuel Assemblies for the Experimental Gas-Cooled Reactor"

3. EGCR-2-3, "Specification for Graphite Support Sleeves for Core I Fuel Assemblies for the Experimental Gas-Cooled Reactor"

4. EGCR-2-4, "Specification for Records to be Kept on Fuel Assemblies for the Experimental Gas-Cooled Reactor"

5. ASTM Designation: A 371, "Specification for CorrosionResisting Chromium and Chromium-Nickel Steel Welding Rods and Base Electrodes" 
EGCR FUEL ASSEMBLY SPECIFICATION

MEYTALLURGY DIVISION

OAK RIDGE NATIONAL IABORATORY
Spec. No. EGCR-2

Date: Nov. 1,1960

Page: $\frac{2}{2}$ of 6

Subject: MASTER SPECIFICATION FOR FUEL ASSEMBLY FOR CORE I OF THE EXPERTMENTAL GAS-COOLED REACTOR

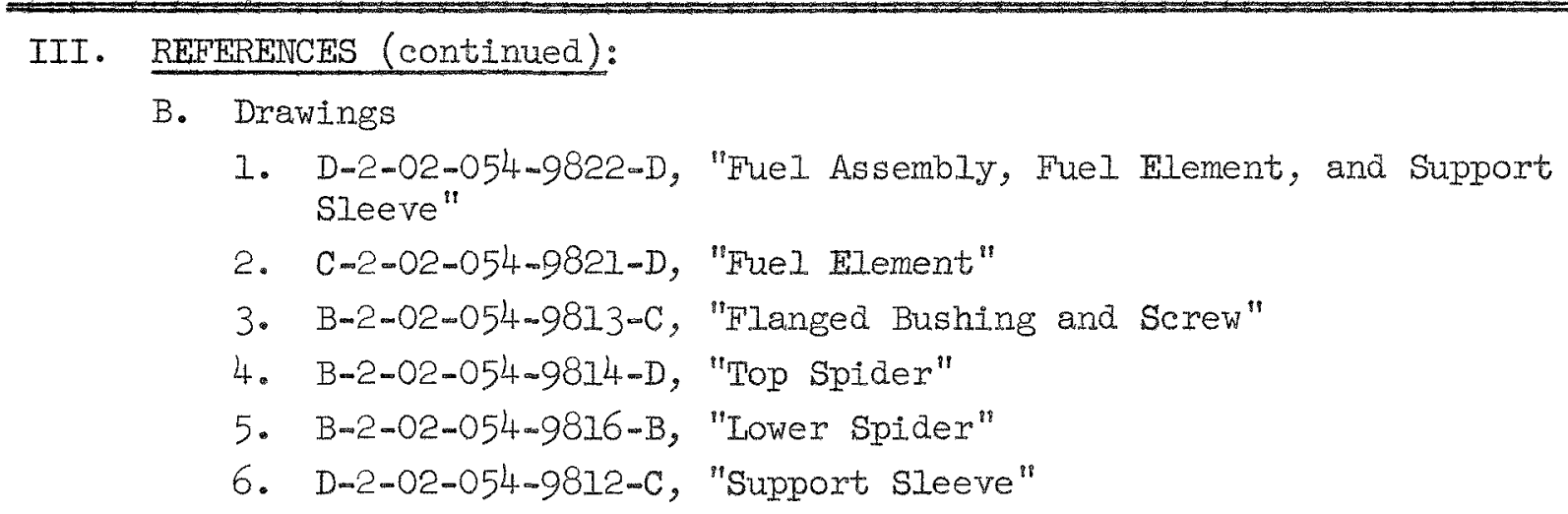

IV. MATERIALS:

Each fuel assembly shall consist of the following components:

\begin{tabular}{lcccl}
\multicolumn{1}{c}{ Component } & Quantity & $\frac{\text { Dwg. No. }}{\text { Spec. No. }}$ & \\
\cline { 4 - 5 } Peripheral Fuel Element & 6 & C-2-02-054-9821-D & EGCR-2-1 \\
Central Fuel Element* & 1 & C-2-02-054-9821-D & EGCR-2-1 \\
Flanged Bushing and Screw & 2 & B-2-02-054-9813-C & None \\
Top Spider & 1 & B-2-02-054-9814-D & EGCR-2-2 \\
Lower Spider & 1 & B-2-02-054-9816-B & EGCR-2-2 \\
Support Sleeve & 1 & D-2-02-054-9812-C & EGCR-2-3
\end{tabular}

After assembly the components shall conform to the requirements specified in the referenced specifications.

V. WELDS:

A. Fuel Elements to Spiders

Each of the seven fuel elements shall be joined to the top spider by welding the top end cap projection to the top spider; only three fuel elements shall be welded to the bottom spider and these three shall be alternate peripheral fuel elements. Each of the welds between the end cap projections and the spiders shall have a minimum penetration of $0.040 \mathrm{in}$. at the original interface and shall be a continuous 360-deg weld. The weld shall contain no roll over; i.e., weld metal shall not be present on the sides of the truncated cones of the spiders. The welds shall be bright and free of cracks as determined by visual inspection. The welds shall be made by the inert-gas shielded, tungsten-are (IIG) method. Filler rod, if used, shall conform with ASTM Designation: A 371, grade ER 308.

* A central fuel element has a mid-plane spacer without fins. A peripheral fuel element has a mid-plane spacer with fins. 


\section{EGCR FUEL ASSEMBLY SPECIFICATION \\ METALLURGY DIVISION \\ OAK RIDGE NATIONAL LABORATORY}

Spec. No. EGCR-2

Date: Nov. 1,1960

Page: $\frac{3 \text { of } 6}{6}$

Subject: MASTER SPECIFICATION FOR FUEL ASSEMBLY FOR CORE I OF THE EXPERTMENTAL GAS-COOLED REACTOR

\begin{abstract}
V. WELDS (continued):
B. Flanged Bushing

Upon completion of the welds jolning the screws to the top spider, the flanged bushing shall make contact with the outside surface of the ring of the top spider.

\section{Screws to Spiders}

The screws shall be joined to the top spider by welding on the inside surface of the spider ring. The welds shall be bright and free of contamination and shall be made by the TIG method.

\section{CLEARANCE:}

There shall be a minimum axial end play of 0.004 in. between the cluster of seven fuel elements and the graphite support sleeve. Thus, when the fuel assembly is upright with the cluster supported and the sleeve unsupported, a minimum clearance of 0.004 in. shall exist between the bottom of the top spider ring and the shoulder of the counterbore in the graphite sleeve.

There sha.1 be a minimum clearance of 0.020 in. between the bottom end of each fuel element and the lower spider. The clearance shall be measured from the surface of the closure weld of each fuel element.
\end{abstract}

VII. ALIGNMENT:

The alignment of the peripheral fuel elements must provide for positioning of mid-plane spacers within 1 deg of true position as shown in Dwg. D-2-02-054-9822-D.

VIII. SPACING:

Minimum spacing between peripheral fuel elements and the bore of the graphite sleeve shalid be 0.110 in.

Minimum spacing between any adjacent fuel elements shall be 0.233 in.

IX. CLEANL INESS:

The fuel assembly shall be free of oil, grease, dirt, or other foreign material as determined by visual inspection. 
EGCR FUEL ASSEMBLY SPECIFICATION
METALIURGY DIVISION
OAK RIDGE NATIONAI LABORATORY
Spec. No. EGCR-2

Date: Nov. 1,1960

Page: 4 of 6

$\begin{array}{ll}\text { Subject: } & \text { MASTER SPECIFICATION FOR FUEL ASSEMBLY FOR CORE I OF THE } \\ & \text { EXPERIMENTIAL GAS-COOLHT REACTOR }\end{array}$

X. IDENTIFICATION:

Each fuel assembly shall exhibit an identification number located on the top surface of the central web of the top spider between an outside cone and the tip of a positioning projection. The identification shall be engraved arabic numbers, starting with 1 and progressing through 1739. The letter "A," "B, or " $\mathrm{C}^{\text {" }}$ shall be added to the identification number to designate the enrichment of $2.2 \%, 2.4 \%$, or $2.6 \%$, respectively. Each digit and letter shall be approx $1 / 16$ in. wide, 1/8 in. long, and. have a minimum depth of 0.020 in.

XI. ACCEPTANCE TESTS:

A. Qualification of Welding Procedure

Prior to the start of manufacture of fuel assemblies, the seller shall be required to demonstrate the capability of his welding procedure to consistently achieve weld penetration in compliance with Section $V-A$ of this specification.

Qualification of the welding procedure shall consist of welding five evaluation samples according to a written procedure. The five evaluation samples shall be welded consecutively. An evaluation"s sample shall consist of seven end caps welded to a top spider. Each of the seven welds in all five evaluation samples shall have a minimum penetration of 0.040 in. as determined by metallographic examination.

B: Visual

Examinations shall be made under direct daylight-type fluorescent illumination of at least 100-ft candles.

1. Welds. - All welds on each fuel assembly shall be examined visualiy to determine weld-surface compliance with requirements of Section $V$ of this specification. If the weld is determined by visual examination to be of questionable quality, it shall be subjected to Iiquid penetrant examination. Cracked welds may be repaired a maximum of two times.

2. Cleanliness. - Each fuel assembly shall be examined visually to determine compliance with requirements of Section IX of this specification.

3. Identification. - Each fuel assembly shall be examined visually to determine compliance with Section $X$ of the specification. 
EGCR PUEL ASSEMBIE SPECIFICATION

METALLURGY DTVISTON

OAK RIDGE NATIONAI, IABORATORY
Spec. No. EGCR-2

Date: Nov. $\frac{1,1960}{5}$

Page: 5 of 6

\section{Subject: MASTIR SPECIFICATION FOR FUEL ASSEMBLY FOR CORE I OF THE EXPERIMENTAL GAS-COOLED REACTOR}

\footnotetext{
XI. ACCEPTANCE TESTS (continued):

4. Bushing-Spider Ring Fit, - Each fuel assembIy shall be examined visually to determine that the flanged bushing is located against the spider ring as required in Section $V$ of this specification。
}

C. Alignment

Alignment jigs capable of ensuring correct alignment as specified in Section VII of this specification shall be fabricated by the seller. Such jigs shall be acceptable only after the ability to consistently ensure correct alignment is demonstrated to the company representative.

\section{Dimensional}

Dimensional inspection of each fuel assembly shall be conducted to determine compliance with tolerances specified in this specification, sections VI and VIII. Go gages shall, be used whenever possible to determine acceptability。

\section{PACKING:}

The procedure for packing and crating the fuel assemblies shall be as follows:

1. Wrap assembly with 1/4-in.-thick corrugated cardboard.

2. Place two 1/4-in.-thick by 4-3/4-in.-diam corrugated cardboard discs in the bottom of a 6-in.-i.d. cardboard mailing tube. The mailing tube shall have a minimum wall thickness of $1 / 4$ in. and shall have a metal bottom and a screw-on type metal cap. The minimum length of the tube shall be 34 in.

3. Pour approx 1-in.othick layer of granulated cork over the discs.

4. Insert wrapped fuel assembly into tube with the top spider at the top of the tube.

5. Pour granulated cork between the assembly and tube and into the center of the sleeve around the stainless steel tubes. Vibrate slightly to pack cork during filling. Fill to within I/2 in. of top of tube.

6. Place two 1/4-in.-thick by 5-3/4-in.-diam corrugated cardboard discs over top of cork.

7. Screw on cap of mailing tube. 


\section{Subject: MASTER SPECIFICATION FOR FUEI ASSEMBLY FOR CORE I OF THE EXPERTMENTAL GAS-COOI,ED REACTOR}

\section{PACKING (continued):}

8. Place 16 packed assemblies on a $4-x-4$ arrangement in a wooden crate constructed of I In. thick wood. Corrugated cardboard shall be used as filler between assemblies and between assemblies and crate to prevent relative movement between the assemblies and the crate. The crate shall have two layers of $1 / 4$-in.-thick corrugated cardboard over the bottom of the crate and between the assemblies and the top of the crate. The assemblies shall be placed in the crate so that the top spider of the assembly is at the top of the crate.

9. The crate shall be clearly marked at several locations to indicate the top of the crate for shipping orientation.

10. The fuel assemblies in each crate shall contain fuel of the same enrichment.

\section{CERTIFICATION:}

The seller shall certify that all requirements of this specification have been met and that all fuel assemblies were subjected to and passed all the acceptance tests required by this specification. Four copies of this certification shall be furnished to the company at the time of shipment. 
EGCR FUEL ASSEMBLY SPECTE ICATION METALIURGY DIVISION

OAK RIDGE NATIONAI IABORATORY

Union Carbide Nuclear Company

A Division of Union Carbide Corporation

Oak Ridge, Tennessee
Spec. No. EGCR-2-1

Date: Nov. I, 1960

Page: 1 of 16

\section{Subject: SPECIFICAIION FOR FUEL ELEMENTS FOR CORE I FUEL ASSEMBLIES FOR THE EXPERIMENTAL GAS-COOLED REACTOR}

\section{SCOPE:}

This specification defines fuel elements consisting of a column of uranium dioxide pellets encased in type 304 stainless steel tubing fitted with top and bottom end caps. The uranium dioxide pellets shall be separated from each end cap by a magnesium oxide pellet. For convenience, the magnesium oxide pellets are in varying thicknesses to minimize by selection the clearance beneath the top end cap. The top and bottom end caps shall be joined to the tubing by closure welds. The fuel element shail contain an inert environment of helium. A spacer shall be attached at the axial mid-point of each fuel element to maintain adequate spacing for coolant flow.

II. MANUFACTURING REQUIREMENTS:

The fuel elements shall be manufactured in accordance with Dwg. C-202-054-9821-D, "Fuel Element," and in accordance with this specification.

The final closure weld shall be made in an atmosphere that contains a minimum of $90 \%$ helium by volume.

The pressure of the atmosphere in which the final closure weld is made shall not vary from atmospheric pressure by more than 2 psi at room temperature. The equipment in which the final closure weld is made shall contain pressure relief valves adequate to ensure maintaining the required pressure within the welding chamber.

All completed fuel elements shall be cleaned to remove traces of nuclear contamination.

III. REFERENCES:

A. Specifications

1. EGCR-2-1-1, "Specification for Fuel Element Tubes for Core I Fuel Assemblies for the Experimental Gas-Cooled Reactor"

2. EGCR-2-1-2, "Specification for Top and Bottom End Caps for Core I Fuel Assemblies for the Experimental Gas-Cooled Reactor"

3. EGCR-2-1-3, "Specification for Uranium Dioxide Fuel Pellets for Core I Fuel Assemblies for the Experimental Gas-Cooled Reactor" 
Subject: SPECIFICATION FOR FUEL ELEMENTS FOR CORE I FUEL ASSEMBLIES FOR THE EXPERIMENPAI GAS-COOLED REACTOR

III. REFERENCES (continued):

4. EGCR-2-1-4, "Specification for Magnesium Oxide Pellets for Core I Fuel Assemblies for the Experimental Gas-Cooled Reactor"

5. EGCR-2-1-5, "Specification for Fuel. Element Spacers for Core I Fuel Assemblies for the Experimental Gas Cooled Reactor ${ }^{98}$

6. ASTM Designation: E 142 - 57 T, "Tentative Method for Controling Quality of Radiographic Nesting"

7. ASTM Designation: $\mathrm{E} 2-49 \mathrm{~T}$, "Methods of Preparation of Micrographs of Metals and Alloys"

8. ASTM Designation: $E_{3}-58 \mathrm{~T}$, "Methods of Preparation of Metallographic Specimens ${ }^{\text {PB }}$

9. ASTM Designation: E $165-60$ T, "Methods for Liquid Penetrant Inspection ${ }^{38}$

B. Drawings

1. C-2-02-054-9821-D, "Fuel Element"

2. B-2-02-054-9818-B, "Fuel Element Tube"

3. B-2-02-054-9817-D, "Fuel Element Spacers"

4. B-2-02-054-9815-C, "Top and. Bottom End Caps"

5. B-2-02-054-9819 B, "Magnesium Oxide Pellet"

6. B-2-02-054-9820-A, "UO2 Pellet"

IV. MATERIALS:

Each fuel element shall consist of the following components:

\begin{tabular}{|c|c|c|c|}
\hline Component & Quantity & Dwg. No. & Spec. No. \\
\hline $\mathrm{UO}_{2}$ Pellet & 36 & $B-2-02-054-9820-A$ & $E G C R-2-1-3$ \\
\hline Fuel Element Tube & 1 & $B-2-02-054-9818-B$ & $E G C R=2-1-1$ \\
\hline Top End Cap & 1 & $B-2-02-054-9815-C$ & $E G C R-2-1-2$ \\
\hline Bottom End Cap & 1 & $B-2-02-054-9815-C$ & $E G C R-2-1-2$ \\
\hline $\begin{array}{l}\text { Magnesium Oxide Pellet } \\
\text { Fuel Element Spacer for }\end{array}$ & 2 & $B-2-02-054-9819-B$ & EGCR $-2-1-4$ \\
\hline $\begin{array}{c}\text { Central Fuel Element } \\
\text { or } \\
\text { Fuel Element Spacer for }\end{array}$ & 1 & $B-2-02-054-9817-D$ & $E G C R-2-1-5$ \\
\hline Peripheral Fuel Element & 1 & $B-2-02-054-9817-D$ & EGCR $-2-1-5$ \\
\hline
\end{tabular}


Subject: SPECIFICATION FOR FUEL ELEMENTS FOR CORE I FUEL ASSEMBLIES FOR THE EXPERIMENTAL GAS-COOLED REACTOR

V. SPACER-TO-TUBE-JOINT:

1. The fuel element spacer shall be joined to the fuel element tube by brazing.

2. The brazed joint shall be a continuous, uniform, fillet joint extending completely around the spacer, as determined by the visual examination described in Section XIII-A-5 of this specification.

3. The brazing alloy shall be GE-81 or equivalent. If GE 81 is used, the chemical composition shall conform to the following:

$$
\begin{array}{lllc}
\text { C } & 0.25 \%(\max ) & \text { P } & 0.03 \% \text { (max) } \\
\text { Si } & 9.75-10.5 \% & \text { AI } & 0.10 \% \text { (max) } \\
\text { Cr } & 18.00-20.00 \% & \mathrm{Ti} & 0.10 \% \text { (max) } \\
\text { Mn } & 1.00 \%(\max ) & \mathrm{Zr} & 0.10 \% \text { (max) } \\
\text { S } & 0.03 \%(\max ) & \mathrm{B} & 10 \mathrm{ppm} \\
& & \mathrm{Ni} & \text { Balance }
\end{array}
$$

4. The thickness of the fuel element tube wall shall not be reduced by more than $0.002 \mathrm{in}$. as a result of dilution by the braze alloy.

5. After brazing, the tube shall be bright and free of contamination.

VI. FUEL LOADING:

The total length of the column of uranium dioxide fuel pellets shall be $26.625+0.000$ in.

The total weight of uranium dioxide shall be $1411 \pm 33 \mathrm{~g}$.

The total length of the column of uranium dioxide fuel pellets and the magnesium oxide pellets shall be $27.000 \pm 0.010 \mathrm{in}$.

VII. INTERNAT ATMOSPHERE:

The atmosphere within the welded fuel element shall be helium with a total gaseous impurity content not exceeding $20 \mathrm{vol} \%$.

The pressure of the atmosphere within the welded fuel element shall not vary from atmospheric pressure by more than 2 psi at room temperature. 
Subject: SPECIFICATION FOR FUEL ELEMENTS FOR CORE I FUEL ASSEMBLIES FOR THE EXPERTMENTAL GAS-COOLED REACTOR

VIII. DRYNESS:

The column of fuel pellets, the magnesium oxide pellets, and the tube shall not contain more than $13 \mathrm{mg}$ of moisture as determined by the dryness test in section XIII-A-I of this specification.

IX. END CAP WELDS:

A. The end caps shall be joined to the tubing by fusion closure welds. The welds shall be made by the TIG method.

B. The welds shall be sufficiently tight so that no leak will be detected by a mass spectrometer calibrated to detect a standard leak of $7 \times 10^{-9}$ standard cc He/sec at room temperature, as specified in Section XII-A-3 of this specification.

C. Each closure weld shall have a minimum penetration of 0.020 in. which shall be determined according to Section XIII-A-4 of this specification.

D. Each weld shall be free of surface cracks, surface porosity, or craters that can be detected visually or with the aid of dye penetrants as specified in Section XIII-A-5 of this specification.

E. Each weld shall be free of internal cracks, volds, porosity, or inclusions that can be detected by the radiographic examination specified in Section XIII-A-2 of this specification.

F. Each weld shall be smooth and bright, and free of contamination as determined by visual inspection.

G. The outside diameter of the fuel element shall not be increased by more than 0.004 in. due to weld roll over.

X. DIMENSIONAL TOLERANCES:

The fuel element shall conform to the dimensional tolerances specified on Dwg. C-2-02-054-9821-D, "Fuel Element," and as outlined in this specification.

XI. SURFACE FINISH AND CONDITION:

The surface finish of the fuel element shall be as specified on Dwg. C-2-02-054-9821-D, "Fuel Element."

All surfaces shall be bright and free of oil, grease, dirt, or other foreign materials as determined by visual inspection. 
EGCR FUEL ASSEMBLY SPECIFICATION METALLURGY DIVISION

OAK RIDGE NATIONAL IABORATORY
Spec. No. EGCR-2-1

Date: Nov. I, 1960

Page: 5 of 16

Subject: SPECIFICATION FOR FUEL ELEMENTS FOR CORE I FUEL ASSEMBLIES FOR THE EXPERTMENTAL GAS-COOLED REACTOR

\section{DIAMETRAI CLEARANCE:}

The diametral clearance between fuel pellet and the capsule tubing shall not exceed 0.006 in.

XIII. ACCEPTANCE TESTS:

A. Nondestructive

1. Dryness Test. - Every one hundredth fuel element shall be selected for dryness tests just prior to performing the final closure weld. The dryness test shall consist of removing the fuel pellets and magnesium oxide pellets from the tube. The fuel pellets, magnesium oxide pellets, and tube shall then be heated for $4 \mathrm{hr}$ at $250^{\circ} \mathrm{C}$ at a pressure not exceeding $1000 \mu$. If the total weight loss of the above components exceeds $14 \mathrm{mg}$ after drying, the remaining 99 fuel elements shall be rejected.

2. Radiographic Examination of Closure Welds. - A sampling as specified in Section XIII-C of this specification shall be $100 \%$ radiographed. Selected welds shall be examined using a radiographic technique* that is consistently capable o"i detecting discontinuities of 0.005 -in. max dimension. Radiographic technique shall be capable, of allowing a complete evaluation of the entire weld area.

A minimum acceptable demonstration will be the visible image of a 0.005-in.-diam hole in a 0.005-in.-thick penetrameter. It is suggested that consideration be given to including holes of 0.010 and 0.0025 -in.-diam in the penetrameter even though the 0.005 in. is used as the reject criterion.

The penetrameter is to be placed in every exposure so that its projected image will be visible through the same metal thickness as is the image of the inspected weld. The penetrameter shall not be in a more favorable orientation than that portion of the weld having the most unfavorable orientation.

Al1 other radiographic requirements shall be in accordance with the recommendations of ASTM Designation: E I42 - $59 \mathrm{~T}$, "Controlling Quality of Radiographic Testing."

*See "Radiography Techniques for End-PIug-to-Tube Welds, "

Section XIV of this specification, for two techniques that might be employed. 


\section{Subject: SPECIFICATION FOR FUEL ELEMENTS FOR CORE I FUEL ASSEMBLIES FOR THE EXPERIMENTAL GAS-COOLED REACTOR}

\section{ACCEPTANCE TESTS (continued):}

d. Technical Requirements:

(1) The instrument sensitivity shall be such that the stable signal from the standard leak, as determined in Section XIII-2-e(3) of this specification, is at least two times as large as the signals produced by background noise.

(2) The inspection shall be performed in a forceventilated location to facilitate the removal of any helium background.

(3) The connecting lines between the test chamber and the instrument manifold shall be as short as is practical and should have a minimum inside diameter of $1 / 2$ in. All connections shall be leaktight.

(4) Care shall be exercised to avoid plugging leaks with any sealant prior to attempted detection with helium.

(5) All assembled fuel elements shall be either heliumleak tested within $24 \mathrm{hr}$ after the final closure weld is completed or stored in a helium atmosphere of pressure equal to or greater than the internal pressure of the fuel element until such time as they can be helium-leak tested. If a fuel element is to be retested or if the testing procedure is intermuted, as in Section XIII-2-e(I), $-e(6)$, and $-e(7)$ of this specification, the fuel element shall be stored in a helium atmosphere as described until such time as testing can be completed. No assembled fuel element shall be allowed to remain in a nonhellum atmosphere for more than a total of $48 \mathrm{hr}$ between the time of its assembly and the completion of helium-leak testing.

e. Testing Procedure:

(1) The performance of the leak-detector equipment shall be verified after each inspection. If at any time this equipment fails to function properly as described in the manufacturer's operating manual, and/or if the sensitivity as determined in Section XIII-2-e(3) of this specification decreases below the minimum level 


\section{Subject: SPECIFICATION FOR FUEL ELEMENTS FOR CORE I FUEL ASSEMBLIES FOR THE} EXPERTMENTAL GAS-COOLED REACTOR

XIII. ACCEPTANCE TESTS (continued):

prescribed in section XIII-2-d(1), the equipment shall be readjusted to function properly and recalibrated, and all fuel elements which have been inspected during the interim since the last satisfactory performance verification of the equipment shall be inspected again.

(2) The closure welds shall be inspected as follows: The assembled, helium-containing fuel elements shall be inspected after the final closure weld has been accomplished by placing the fuel element in the inspection chamber, evacuating the chamber, and searching for helium leaks as prescribed in the instrument manufacturer's operating manual.

(3) The instrument shall be calibrated as follows: The standard leak source $\left(7 \times 10^{-9} \mathrm{std} \mathrm{cc} / \mathrm{sec}\right)$ shall be connected to one end of the test chamber. The opposite end of the test chamber shall be connected to the manifold, and the time which is required to produce a signal two times as large as the background noise shall be measured. This measurement shall be accomplished while examining a 100\% sample from the test chamber and with all valves between the standard leak source and the helium-sensing device completely open. This portion of the calibration shall be continued until the signal from the standard leak reaches a stable amplitude. The signal. amplitude and manifold pressure shall be measured at this point.

(4) The inspection shall be made taking a sample from the test chamber. All valves between the fuel element and the helium-sensing device shall be completely open and the time of inspection shall be no less than one minute and at least twice as long as the time, as determined. in Section XIII-2-e(3) of this specification for that particular method, required for the standard leak to produce a signal two times as large as the background. noise. 
EGCR FUEL ASSEMBLY SPECIFICATION

METALIURRY DIVISION

OAK RIDGE NATIONAL LABORATORY

Spec. No. EGCR-2-1

Date: Nov. 1,1960

Page: 9 of 16

Subject: SPECIFICATION FOR FUEL ELEMENTS FOR CORE I FUEL ASSEMBLIES FOR THE EXPERIMENTAL GAS-COOLED REACTOR

XIII. ACCEPTANCE TESTS (continued):

(5) The manifold pressure at which the inspection is made shall be the same as the pressure at which the instrument is calibrated, as measured in section XIII-2-e(3) of this specification.

(6) Excessive pump-down time shall be indicative of an external leak. The leak shall be located and corrected before further testing is accomplished.

(7) During the inspection, any signal which produces an indication two times as large as the background noise level shall be indicative of a through path or leak in the fuel element being inspected and that fuel element shall be rejected. If more than one assembled fuel element is being inspected at the time a leak is detected, the fuel elements shall be inspected again such that the leaking fuel element or elements are identified and rejected.

(8) All rejected, assembled fuel elements shall be disassembled. Any salvageable parts of the rejected. fuel elements may be reused in the assembly of other elements. A salvageable item is an item that is reinspected and found to conform to the specification.

4. Penetrant Inspection of Closure Welds. - Each weld shall be 100\% examined for discontinuities in accordance with ASTM Designation: E $165-60 \mathrm{~T}$, "Methods for Iiquid Penetrant Inspection," except as follows:

a. "Method A, Procedure A-2" shall be followed except as modified by paragraphs $b$ through $h$ below.

b. Precleaning shall be accomplished by vapor degreasing.

c. Minimum penetrant soak time shall be $30 \mathrm{~min}$.

d. Emulsification time shall be held to a minimum required to permit removal of excess penetrant and shall not exceed 3 min.

e. Drying shall be accomplished by circulating air of $170^{\circ} \mathrm{F}$ or less for a period of time that will not cause evaporation of penetrant. 
EGCR FUEL ASSEMBLY SPECIFICATION

METALIURGY DIVISION

OAK RIDGE NATIONAI LABORATORY
Spec. No. EGCR-2-1

Date: Nov. I, 1960

Page: 10 of 16

\section{Subject: SPECIFICATION FOR FUEL ELEMENTS FOR CORE I FUEL ASSEMBLIES FOR THE EXPERIMENTAL GAS-COOLED REACTOR}

XIII. ACCEPTANCE TESTS (continued):

f. Dry-powder developer shall be used. The powder shall remain on the part for a minimum of ten minutes prior to inspection.

g. Magnaflux ZI 22 penetrant or equivalent shall be used. "Equivalents" shall be approved by the company.

$h$. If the first closure weld is inspected prior to performance of the second closure weld, no penetrant shall. be allowed inside the tube.

i. All indications shall be evaluated by visual means in accordance with Section XIII-A-5 of this specification. If there is no visual evidence of a discontinuity, the weld shall be reprocessed through the penetrant inspection. Reappearance of the penetrant indication shall cause the piece to be rejected.

5. Visual Examination. - AII end closure welds and heat affected. zones shall be visually examined for evidence of folds, cracks, surface porosity, and surface inclusions, using optical magnification of $3 \mathrm{X}$ to $6 \mathrm{X}$. Discontinuities having depths in excess of 0.0025 in. shall cause the fuel element to be rejected.

All spacer-to-tube-joint brazing shall be visually examined to determine conformance with Section $V$ of this specification.

Visual examinations shall be made under direct daylight-type fluorescent illumination of at least 100-ft candles.

6. Dimensional Inspection. - A sampling of the completed fuel elements selected as specified in section XIII-C of this specification shall be dimensionally inspected for conformance with the dimensional tolerances specified on Dwg. C-2-02-054-982l-D, "Fuel Element," and with this specification. This inspection applies to all specified dimensions that can be measured after completion of the fuel element without rendering it unacceptable for the intended use. 
EGCR FUEL ASSEMBLY SPECIFICATION

METALLURGY DIVISION

OAK RIDGE NATIONAL IABORATORY
Spec. No. EGCR-2-1

Date: Nov. 1, 1960

Page: 11 of 16

Subject: SPECIFICATION FOR FUEL ELEMENTS FOR CORE I FUEL ASSEMBLIES FOR THE EXPERTMENTAL GAS-COOIED REACTOR

XIII. ACCEPTANCE TESTS (continued):

B. Destructive

1. Metallographic Examination to Determine Weld Penetration. -

a. A sample of one percent of the fuel elements shall be selected for examination after meeting the nondestructive testing requirements as stated in section XIII-A of this specification. The fabrication of unloaded fuel elements for this test is acceptable. If one or more fuel elements of the one percent random sample are rejected, then double the number of fuel elements shall be selected for testing. If one or more of the second group are determined to be rejectable, then the entire lot will be considered rejectable and the manufacturer will be responsible for initiation of corrective action. After initiation of corrective action, sampling will again go into effect as described above.

b. The fuel element shall be sectioned longitudinally through the weld area at approx 90-deg intervals, thus permitting four penetration measurements on each weld. (One section shall be made at the location where welding was stopped.) One half of the sample fuel elements shall be sectioned at the initial closure weld and the remainder at the final weld.

c. The sections shall be prepared for examination, metallographically measured, and photographed as specified in ASTM Designations: E 2 - 49 T and E $3-58$ T unless otherwise specified in this specification. The photographs shall become the property of the company and shall be delivered with or prior to final shipment.

2. Metallographic Examination to Determine Dilution of Tube Wall by Brazing Alloy. - The fuel elements selected for weldpenetration determination shall also be sectioned longitudinally through the brazed area and prepared for examination to determine tube-wall dilution by the brazing alloy. These samples shall be prepared in the same manner and to the same ASTM specification requirements as described for the determination of weld penetration. 
EGCR FUEL ASSEMBIY SPECIFICATION

METAILURGY DIVISION

OAK RIDGE NATIONAL IABORATORY

Spec. No. EGCR-2-I

Date: Nov. 1,1960

Page: 12 of 16

Subject: SPECIFICATION FOR FUEL ELEMENTS FOR CORE I FUEL ASSEMBIIES FOR THE EXPERIMENTAL GAS-COOLED REACTOR

XIII. ACCEPTANCE TESTS (continued):

If no rejects due to examination of brazed joints are found in the initial one percent sample, the metallographic examination of brazed areas need not be continued on the double sample. However, if one or more fuel elements of the one percent sample are rejected, the same requirements for double second sampling and corrective action shall apply as specified in Section XIII-B-I of this specification.

C. Statistical Sampling Plan

A modified, one-sided sequential sampling plan for radiographic and dimensional acceptability will be employed until an acceptable quality level (AQL) of 0.0001 is demonstrated; thereupon, a single sampling plan will be used. The sequential sampling plan is based on an AQI of 0.0001 , a lot tolerance fraction defective of 0.01 , and $\alpha=\beta=0.01$.

One hundred percent inspection will be performed until the number of defective fuel elements satisfies the following equation:

$$
C=0.002156 \mathrm{~N}-0.995666
$$

where $\mathbb{N}$ is the number inspected and $C$ is the number rejected. This equation is shown in Fig. I; for example, if there are no defective elements among the first 462 inspected, then the single sampling plan will thereafter be used.

The single sampling plan is to be used as follows: From each group of 41 fuel elements, 10 will be inspected. If there are no defective elements, the group will be accepted; if one or more defective elements are detected, the group must be $100 \%$ inspected.

XIV. RADIOGRAPHY TECHNIQUES FOR END-PLUG-TO-TUBE WELDS:

One technique (illustrated in Fig. 2) involves radiographing directly through the $0.200-i n$ - diam pin of the end cap. The type 304 stainless steel mask that fits snugly around the cap configuration increases the total thickness of the metal to 0.250 in. between the radiation source and the weld. The minimum detectable defect size is approx 0.004 in. to 0,006 in., as limited by the film and other considerations exclusive of the specimen thickness. This minimum size is still attainable through the $0.250 \mathrm{~m}$ in. mask even though the available subject contrast is decreased. The principal advantage of the mask is that undercut and scatter from the pin is eliminated and a uniform exposure is 
Subject: SPECIFICATION FOR FUEL ELEMENTS FOR CORE I FUEL ASSEMBLIES FOR THE EXPERIMENTAL GAS-COOLED REACTOR

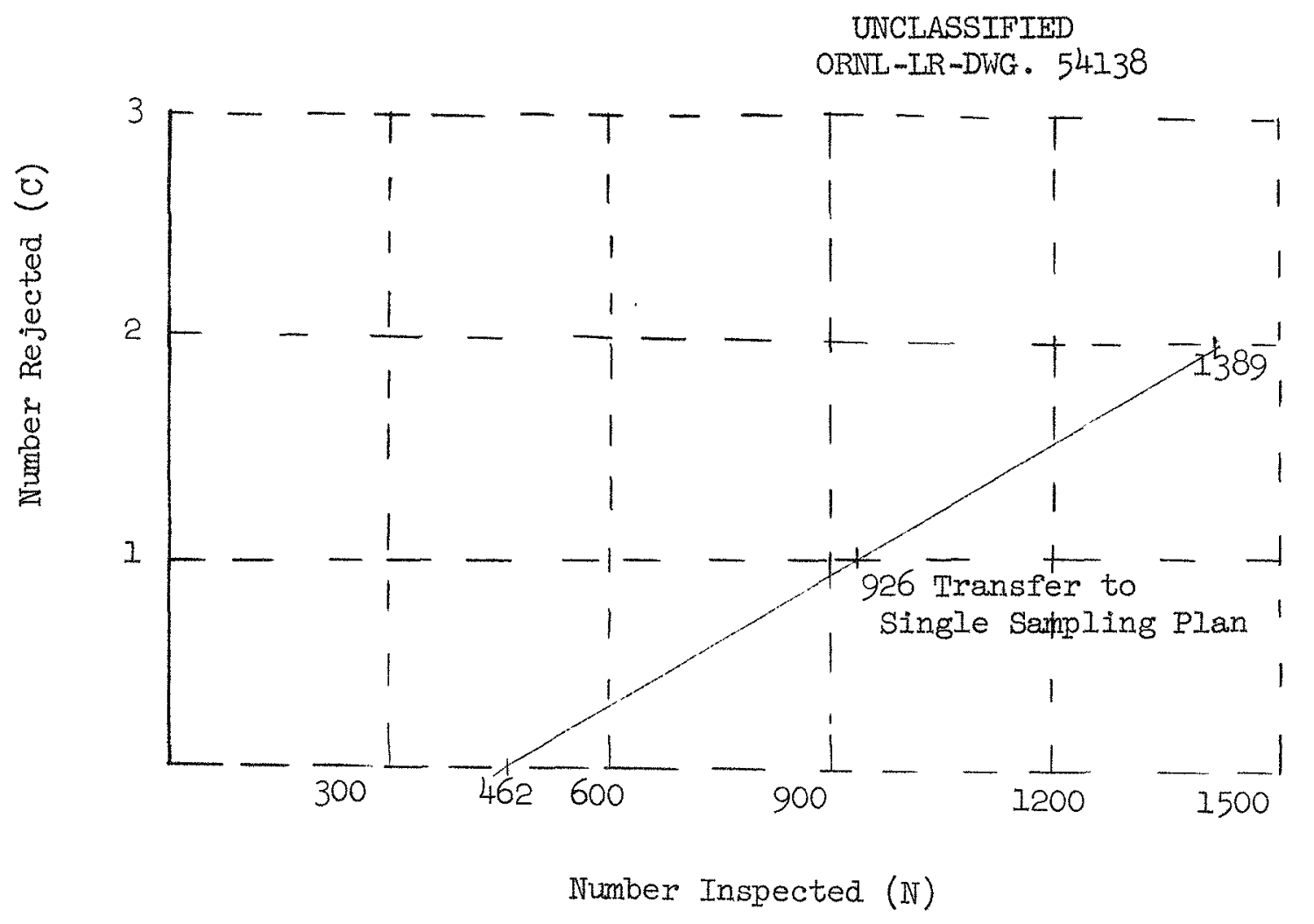

Fig. I. Sampling Plan for Radiographic and Dimensional Inspection of Fuel Elements. 
EGCR FUEL ASSEMRLY SPECIFICATION

METAILURGY DIVISION

OAK RIDGE NATIONAI, IABORATORY
Spec. No. EGCR-2-I

Date: $N o v_{-1,1960}$

Page: 14 of 16

\section{Subject: SPECIFICATION FOR FUEL ELEMENTS FOR CORE I FUEL ASSEMBLIES FOR THE EXPERIMENTAL GAS-COOLED REACTOR}

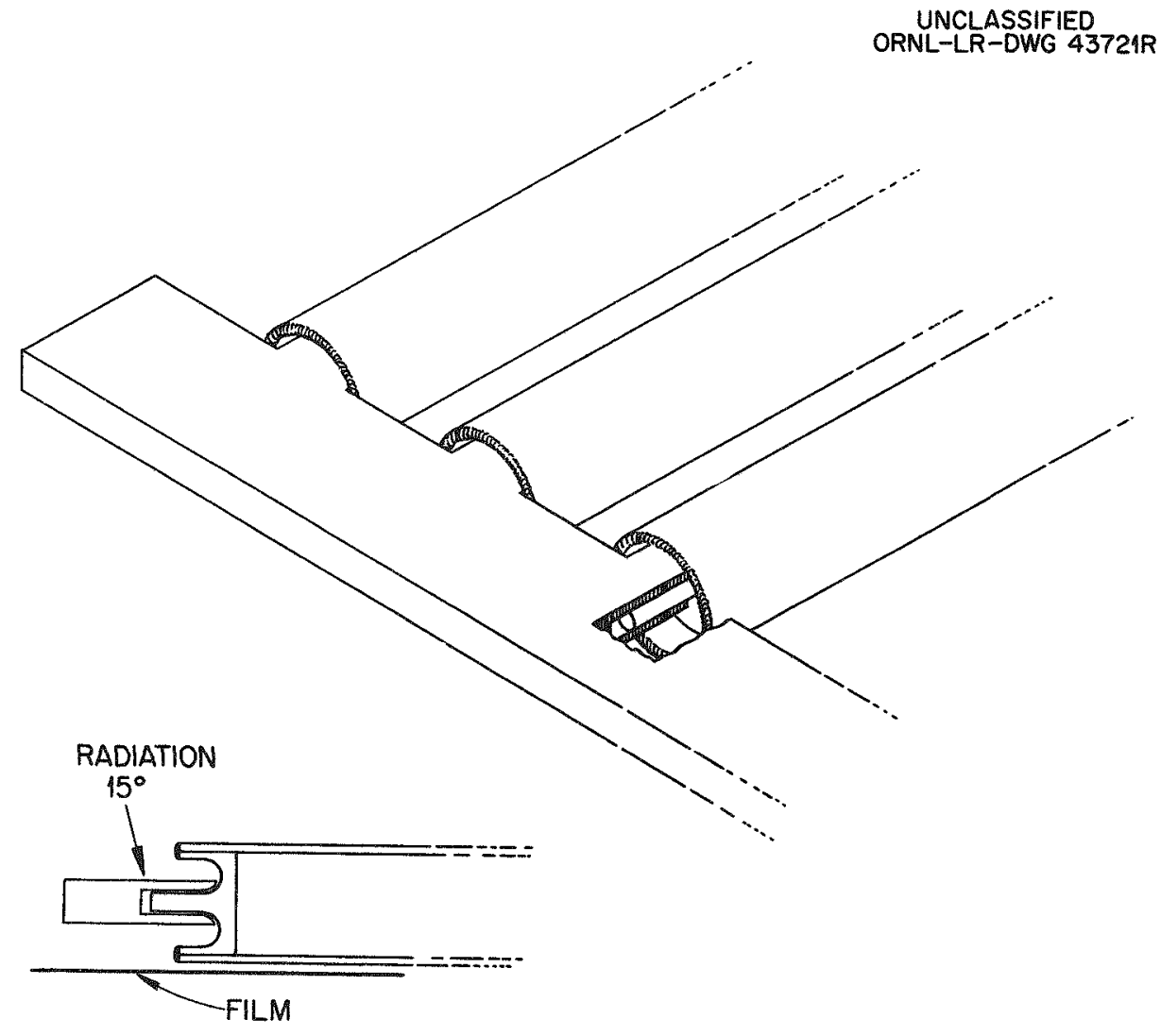

Fig. 2. One of Two Suggested Techniques for Radiographic Examination of Fuel Element Closure Welds. This technique involves radiographing directly through the end cap pin. The type 304 stainless steel mask which fits over the pin increases the total thickness of the metal to $0.250 \mathrm{in}$. The mask eliminates undercut and scatter from the pin so that a uniform exposure is attained cver the portion of the weld being examined. 
EGCR FUEL ASSEMBLY SPECIFICATION

Spec. No. EGCR-2-1

METALLURGY DIVISTON

OAK RIDGE NATIONAI LABORATORY

Date: Nov. I, 1960

Page: 15 of 16

Subject: SPECIFICATION FOR FUEL ELEMENTS FOR CORE I FUEL ASSEMBLIES FOR THE EXPERIMENTAL GAS-COOLED REACTOR

XIV. RADIOGRAPHY TECHNIQUES FOR END-PLUG-TO-TUBE WELDS (continued):

attained over the portion of the weld being examined. This technique requires five exposures around the circumferential weld at 72-deg intervals. The penetrameter used is a 0.005 -in.-thick shim of type 304 stainless steel containing a 0.005-in.-diam hole. This is placed on the mask and the image of the $0.005-i n$. hole is plainly visible on all radiographs.

The second radiographic technique is illustrated in Fig. 3. The weld bead is projected slightly and the fuel element is inclined at an angle so as to prevent the pin from interfering with the weld image. This technique achieves better contrast due to the reduced thickness of the specimen; however, the minimum detectable defect size is still essentialiy the same. Some interpretation difficulties are encountered with this technique due to the very small weld image and the rapidly changing thickness through which the radiation passes immediately adjacent to the weld, $1 . e$. , the thickest portion of the cap.

XV. CERTIFICATION AND TEST REPORTS:

At the time of shipment, the seller shall furnish the company four copies of a certification stating that all requirements of this specification have been met.

The seller shall also furnish four certified copies of dryness test reports. These reports shall include initial weights, final weights, weight loss, and fuel element number. 
EGCR FUEL ASSEMBLY SPECIFICATION METAIIURGY DIVISION

OAK RTDGE NATIONAI LABORATORY
Spec. No. EGCR-2-1

Date: Nov. I, 1960

Page: of 16

Subject: SPECIFICATION FOR FUEL ELEMENTS FOR CORE I FUEL ASSEMBIIES FOR THE EXPERIMENTAI GAS-COOIED REACTOR

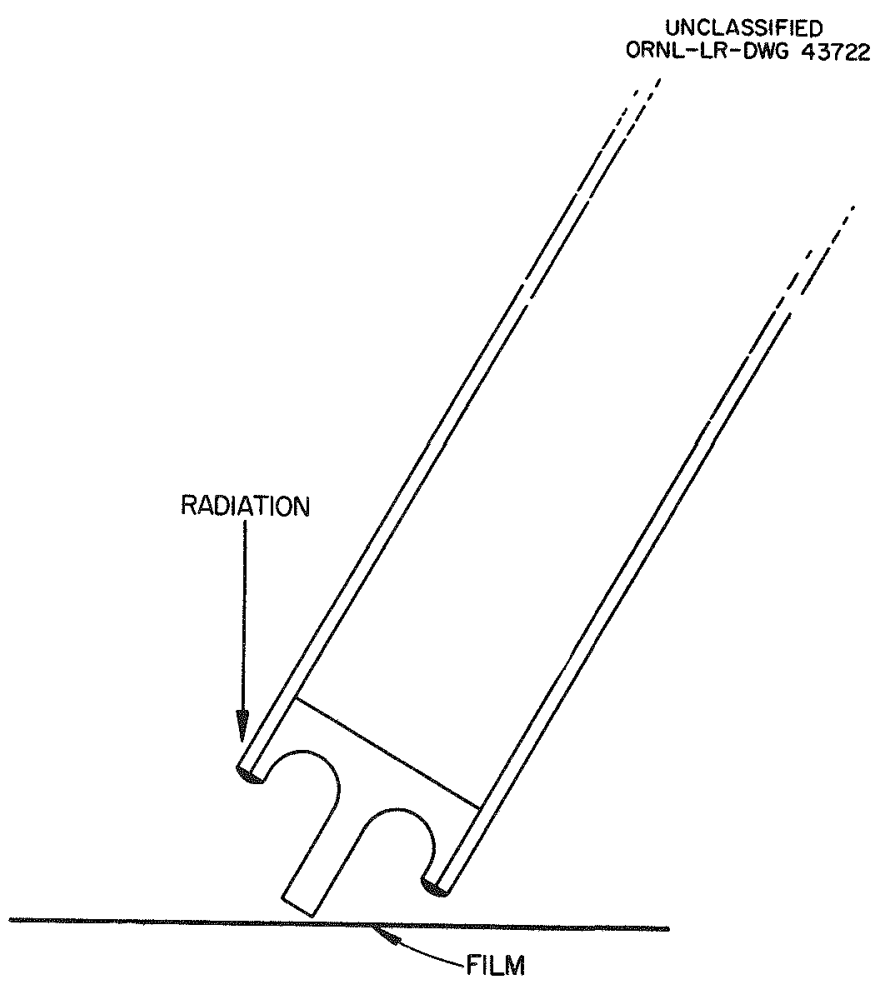

Fig. 3. The Second of Two Suggested Techniques for Performing Radiographic Examination of Fuel glement Closure Welds. The weld head is projected slightly with the fuel element being inclined to prevent the pin from interfering with the weld image. 


\section{EGCR FUEL ASSEMBLY SPECIFICATION \\ METAIIURGY DIVISION \\ OAK RIDGE NATIONAL IABORATORY}

Union Carbide Nuclear Company

A Division of Union Carbide Corporation

Oak Ridge, Tennessee
Spec。 No。 EGCR-2-1-1

Date: Nov. 1,1960

Page: 1 of 9

\section{Subject: SPECIFICATION FOR FUEL ELEMENT TUBES FOR CORE I FUEL ASSEMBLIES FOR THE EXPERIMENTAL GAS-COOLED REACTOR}

\section{SCOPE:}

This specification defines seamless, cold-drawn type 304 stainless steel tubing with an inside diameter of 0.710 in. and a wall thickness of 0.020 in. All requirements of the latest revision of ASTM Designation: A 269 shall apply except as specifically modified in this specification.

II. MANUFACTURING REQUIREMENTS:

Tubes shalf be manufactured in conformance with Dwg. B-2-02-054-9818-B and with this specification.

Tubes shall be extruded or pierced, hot-rolled and cold-drawn, or reduced to specific size.

III. REFERENCES:

Dwg. B-2-02-054-9818-B, "Fuel Element Tube"

ASTM Designation: A 269 - 59 T, "Specification for Seamless and Welded Austenitic Stainless Steel Tubing for General Service".

ASTM Designation: E 165 - 60 T, "Methods for Liquid Penetrant Inspection"

AISI, sept., 1957, "Steel Tubular Products"

IV. CHEMICAL COMPOSITION:

The chemical composition of the austenitic steel used shall conform to the requirements of the latest revision of ASTM Designation: A 269 , grade TP 304. The steel shall also conform to the following requirements:

$\begin{array}{ll}\text { Carbon } & 0.04 \text { wt } \% \text { (min) } \\ \text { Cobalt } & 0.2 \text { wt } \% \text { (max) } \\ \text { Boron } & 10 \mathrm{ppm} \text { (max) }\end{array}$


Subject: SPECIFICATION FOR FUEL ELEMEITI TUBES FOR CORE I FUEL ASSEMBLIES FOR THE EXPERTMENTAL GAS-COOLED REACTOR

V. PHYSICAL PROPERTIES:

The tubing shall be furnished in the annealed condition and free of intergranular attack. However, a maximum of $10 \%$ residual cold work for size control will be allowed. The annealed tubing shall have a maximum Rockwell hardness number of B 90. The tubing shall also conform to the hydrostatic test requirements specified in the latest revision of ASTM Designation: A 269.

VI. DIMENSIONS AND TOLERANCES:

A. The inside diameter shall be $0.710+0.002$ in. "Inside diameter" here does not mean "average inside äiameter," but refers to actual diameter at any given plane perpendicular to the axial centerline.

B. The wall thickness shall be $0.020 \pm 0.002$ in. "Wall thickness" does not mean "average wall thickness," but refers to wall thickness in any plane normal to the axial centerline. All dimensional tolerance measurements shall be made after the hydrostatic test is performed.

C. The tubing shall be furnished in lengths of $27.500+0.015$ in.

D. The tube ends shall be perpendicular to the outside surface within 0.005 in.

E. Corners formed by ends of tubing and Iongitudinal surfaces shall be square and deburred with a maximum chamfer of 0.005 in.

Fo The tubing shall be straight within 0.030 in. per 3-ft length a.s stated in AISI, Sept., 1957, "Steel Tubular Products."

VII. SURFACE FIVISH AND CONDITION:

The tubing shall have a bright surface finish on the inside surfaces and shall be free of scale and oxide film or other foreign materials as determined by visual inspection. The outside surface shall be polished, using a belt of 320 grit or finer. Tubing shall be furnished free of seams, cracks, laps, and intergranular attack. Al.1. inclusions, pits, gouge marks, and score marks in excess of 0.0025 in. shall be cause for rejection. Discontinuities which individually would be considered nonrejectable are to be considered rejectable defects if they occur as multiples around any circumference of the tube or if they are aligned along an element of the tube. 
EGCR FUEL ASSEMBLY SPECIFICATION

Spec. No. EGCR-2-1-1 METAILURGY DIVISION

OAK RIDGE NATIONAL LABORATORY

Date: Nov. I, 1960

Page:

3 of 9

Subject: SPECIFICATION FOR FUEI ELEMENTI TUBES FOR CORE I FUEI ASSEMBLIES FOR THE EXPERTMENTAL GAS-COOLED REACTOR

\section{ACCEPTANCE TESTS:}

A. Nondestructive

1. Liquid Penetrant. - A 100\% liquid-penetrant inspection shall be performed by the seller on the entire outside diameter surface of the finished tubes in accordance with ASTM Designation: E $165-60$ T, "Methods for Liquid Penetrant Inspection," except as specifically modified below:

a. Precleaning to the extent necessary to remove all foreign material that might obscure test results shall be accomplished by vapor degreasing.

b. Only "Method A, Procedure A-2" is considered an acceptable procedure.

c. Penetrant shall remain on the tubes for a minimum of 30 min.

d. Penetrant shall be Magnaflux zI 22 or equivalent. "Equivalent" shall be approved by the company.

e. Emulsification time shall be held to a minimum required to remove excess penetrant but not to exceed $2 \mathrm{~min}$.

f. Drying shall be accomplished by circulating air at $170^{\circ} \mathrm{F}$ or less for a time that will not cause evaporation of the penetrant.

g. Dry-powder developer shall be used. The powder shall remain on the tubes a minimum of $10 \mathrm{~min}$ prior to inspection.

h. All penetrant indications shall be evaluated to determine if requirements of Section VII of this specification are satisfied.

i. Reinspection after removal of defects is required. 
EGCR FUEL ASSEMBLY SPECIFICATION

METALLURGY DIVISION

OAK RIDGE NATIONAI IABORATORY
Spec. No. EGCR-2-I-1

Date: Novo 1,1960

Page: 4 of 9

Subject: SPECIFICATION FOR FUEL ELEMENT TUBES FOR CORE I FUEL ASSEMBLIES FOR THE EXPERIMENTAL GAS-COOLED REACTOR

VIII. ACCEPTANCE TESTS (continued):

2. Eddy Current. - Eddy-current inspection shall be performed on all tubes as follows:

a. Technical Requirements:

(1) The tubing shall be inspected in random lengths prior to cutting the tubing to the specified lengths. The uninspected ends (refer to section VIII-2-c of this specification) shall be removed before cutting the acceptable tubing to the specified lengths.

(2) The inspection shall be accomplished by an inspector whose competence is certified by the seller.

(3) The inspection equipment used shall be suitable as described in Section VIII-2-b of this specification.

(4) The defective portion of tubing classified "rejected" according to the provisions of section VIII-2-c of this specification shall be removed prior to cutting the tubing to final length. The defective section shall be marked in such a manner that it is clearly indicated that the defective section has been rejected by the eddy-current inspection.

(5) The inspection procedure shall be in accordance with Section VIII-2-c of this specification.

(6) Standardiation of the inspection shall be accomplished according to the provisions of section VIII2-d of this specification.

(7) The tubing shall be inspected at the completion of the manufacturing process or immediately prior to the final anneal and straightening operation. No drawing operation shall be accomplished after the eddy-current examination. 
EGCR FUEL ASSEMBLY SPECIFICATION

METAILURGY DIVISION

OAK RIDGE NATIONAL LABORATORY
Spec. No. EGCR-2-I-I

Date: Nov, I, 1960

Page: 5 of 9

Subject: SPECIFICATION FOR FUEL ELEMENT TUBES FOR CORE I FUEL ASSEMBLIES FOR THE EXPERIMENTAL GAS-COOLED REACTOR

VIII. ACCEPTANCE TESTS (continued):

b. Inspection Equipment:

(1) Inspection shall be accomplished using an encircling(feed-through) coil system.

(2) The mechanism used to drive the tubing through the coil system shall be capable of operating at a constant speed and shall be free from jerking and excessive vibration.

(3) The sensitivity of the instrumentation shall be such that the provisions of Section VIII-2-c of this specification can be accomplished.

(4) Signals from the inspection equipment shall be displayed in such a manner that the presence of a defect is clearly indicated.

c. Inspection Procedure:

(1) A standard reference tube fabricated according to Section VIII-2-d of this specification shall be used to establish the sensitivity and response of the inspection system.

(2) The tubing shall be driven through the coil system at a uniform rate of speed. The speed shall be in conformance with the capabilities of the inspection instrumentation and the operator to clearly detect the signal produced by the standard defect in the standard reference tube.

(3) The equipment shall be adjusted in such a manner that a clear indication of the presence of the standard defect in the reference tube is obtained.

(4) The operating frequency of the instrument shall be chosen as low as possible, consistent with the reliable detection of the standard defect, but the frequency shall not exceed the maximum frequency calculated by the following formula:

$$
\begin{aligned}
F_{\text {max }}=\frac{36.5}{D^{2}} \mathrm{kc} \quad \text { where } F & =\text { Frequency }(\mathrm{kc}) \\
D & =\text { NominaI Tubing } \\
& \text { Diameter (In.) }
\end{aligned}
$$


EGCR FUEL ASSEMBLY SPECIFICATION

METALLURGY DIVISION

OAK RIDGE NATIONAI LABORATORY
Spec. No. EGCR-2-1-1

Date: Nov. 1, 1960

Page: $\frac{6}{6}$ of 9

Subject: SPECTFICATION FOR FUEL ELEMENT TUBES FOR CORE I FUEL ASSEMBLIES FOR THE EXPERIMENTAL GAS-COOLED REACTOR

VIII. ACCEPTANCE TESTS (continued):

(5) The standard reference tube shall be used periodically to check the performance of the inspection. If at any time the equipment fails to produce a clear indication of the presence of the standard defect, the equipment shall be readjusted to give a clear indication, and all tubing which has been inspected during the interim since the last satisfactory standardization shall be inspected again.

(6) Any portion of the tubing which produces an indication as large or larger than the average indication produced by the standard notches in the standard reference tube as defined in section VIII2-d of this specification shall be rejected.

(7) If a phase detector is being utilized in the inspection equipment, the phase control shall be adjusted such that a phase shift of 10 deg in either direction from the operational setting will not reduce the size of the indication from the standard defect more than $15 \%$.

(8) The tubing shall be inspected by feeding it through the coll system in the direction which produces the most sensitive inspection.

(9) A test shall be devised by the seller to determine the length of the uninspected ends of the tubing.

d. Standard Reference Tube:

(1) Standard reference tubes shall be fabricated from tubing taken from the same heat and manufactured by the same processes as the tubing to be inspected.

(2) Standard reference tubes shall be approx 5 ft long.

(3) Iongitudinal notches shall be cut on the outside surface of the tube at approx 3-in. intervals along the tube beginning 6 in. from each end of the tube. The notches shall be cut with an electrical-sparkdischarge machine using a tool 0.004 in. thick and 1/4 in. long having a 1/16-in. radius at each end. The notches shall have a depth equal to $12.5 \%$ of the wall thickness. Any alternate method of notch making must have prior approval of the company. 
EGCR FUEL ASSEMBLY SPECIFICATION

METALIURGY DIVISION

OAK RIDGE INATIONAL IABORATORY
Spec. No. EGCR-2-1-1

Date: Nov. 1, 1960

Page:

Subject: SPECIFICATION FOR FUEL ELEMEITI TUBES FOR CORE I FUEI ASSEMBLIES FOR

THE EXPERTMENTAL GAS-COOLED REACTOR

\section{ACCEPTANCE TESTS (continued):}

(4) The standard reference tube shall be examined with the eddy-current equipment. The average signal produced by the notches shall be determined and the depth of one of these notches which produces a signal equal to or greater than the average notch signal shall be accurately measured. If the depth of this notch is not greater than $12.5 \%$ of the wall thickness, the tube may be used as the standard reference tube for calibrating the eddy-current equipment.

(5) Any defect indication which may be present in the standard reference tube shall not be allowed to interfere with the identity or evaluation of the standard defects.

(6) The standard reference tube shall be examined visually in the region of the standard defect to determine any damage to the tube as a result of the machining operation. The tubing shall be free of scores, dents, burrs, and other marks in the region of the standard defect.

3. Hydrostatic Test. - Each tube shall be tested at a hydrostatic pressure of 800 psi prior to dimensional inspection.

4. Dimensional Inspection. -

a. Mechanical measurements of the wall thickness shall be made at $90-\mathrm{deg}$ intervals or less on each end of each tube (cut to length) to determine compliance with Section VI-B of this specification.

b. Each finished tube shall be subjected to an air-gage inspection of the inside diameter to determine compliance with Section VI-A of this specification. Diametral measurements shall be made at intervals of approx 90 deg.

c. A random $1.0 \%$ sample of the tubes in finished condition and cut to length shall be subjected to an ultrasonic-resonancetype inspection for wall-thickness determination. The accuracy of the test equipment for use in this measurement sha.l be established by taking readings at a point near the end of one or more tubes and checking by measurement with a micrometer. 
EGCR FUEI ASSEMBLY SPECIFICATION METAILURGY DIVISION

OAK RIDGE NATIONAT IABORATORY
Spec. No. EGCR-2-I-1

Date: Nov. 1,1960

Page: $\frac{8 \text { of } 9}{9}$

\section{Subject: SPECIFICATION FOR FUET EIFMENT TUBES FOR CORE I FUEL ASSEMBLIES FOR THE EXPERIMENTAL GAS-COOLED REACTOR.}

\section{ACCEPTANCE TESTS (continued):}

A continuous helical scan shall be accomplished on the inspected tubing with a pitch not to exceed one inch. An acceptable alternate will be circumferential scans on oneinch centers. If one or more tubes of the $10 \%$ sampling are determined not to meet the dimensional requirements as stated in this specification, an additional $20 \%$ sampling shall be examined in the same manner. A rejection rate of $10 \%$ or more of the tubes tested shall be cause for $100 \%$ inspection of the entire lot.

Tubes not subjected to ultrasonic resonance tests for wall thickness by the seller are subject to such tests by the company. The tubes are subject to rejection if the tests by the company show that the wall thickness does not conform to the dimensional requirements of this specification.

d. The seller shall perform inspection on each tube for length, end squareness, and straightness to determine compliance with Sections VI-C, VI-D, and VI-F, respectively, of this specification.

5. Visual. - Each tube shall be visually inspected under direct daylight-type fluorescent lighting of at least 100-ft candles to ensure conformance to section VII of this specification.

B. Destructive

1. Metallographic exarnination at $100 \mathrm{x}$ of one section of tubing selected at random from each lot shall be prepared to determine compliance with Section $V$ of this specification.

2. Metallographic specimens shall be forwarded by the seller to the company at tine of shipment.

IX. MARKINGG AND PACKING:

A. Each tube shall be marked with a continuously recurring legend using nonmetallic inks (nonsulfur bearing) which are not water soluble. The marking shall Include the words "TP 304 " and "ASTM A $269 "$ as well as heat number, size, and manufacturer's name or trademark. The marking shall be done after dyepenetrant inspection. 


\section{EGCR FUEI ASSEMBLY SPECIFICATION METALLURGY DIVISION \\ OAK RIDGE NATIONAL LABORATORY}

Spec. No. EGCR-2-1-1 Date: Nov. 1, 1960

Page: 9 of 9

\section{Subject: SPECIFICATION FOR FUEL ELFMENT TUBES FOR CORE I FUEL ASSEMBLIES FOR THE EXPERIMENTAI GAS-COOLED REACTIOR}

\section{MARKING AND PACKING: (continued):}

B. Each tube shall be packed in such a manner as to prevent damage and to maintain the cleanliness of the tubing during handing and shipment.

\section{TEST REPORTS:}

Four certified copies of test reports shall be furnished by the seller to the company at the time of shipment of each lot of material. At the time of shipment, the seller shall also furnish to the company four copies of a certification stating all requirements of this specification have been met. 
EGCR FUEL ASSEMBLY SPECIFICATION METALLURGY DIVISION OAK RIDGE NATIONAL LABORATORY

Union Carbide Nuclear Company A Division of Union Carbide Corporation Oak Ridge, Tennessee
Spec. No. EGCR-2-1-2 Date: Nov. 1,1960

Page: 1 of 3

\section{Subject: SPECIFICATION FOR TOP AND BOTIOM END CAPS FOR CORE I FUET ASSEMBLIES FOR THE FXPERIMENTAI GAS-COOLED REACTOR}

\section{SCOPE:}

This specification defines type 304 stainless steel end caps, 0.710 in. in diameter.

II. MANUFACTURING REQUIREMENTS:

The top and bottom end caps shall be manufactured in conformance with Dwg. B-2-02-054-9815-C and with this specification.

The end caps shall be manufactured from wrought bar stock by machining or by forging and machining.

III. REFERENCES:

Dwg. B-2-02-054-9815-C, "Top and Bottom End Caps"

ASIM Designation: A 276 - 57 T, "Specification for Hot-Rolled and ColdFinished Corrosion-Resisting steel Bars"

A.STM Designation: E 165 - 60 T, "Methods for Liquid Penetrant Inspection"

IV. CHEMICAI COMPOSITION:

The chemical composition of the steel used shall conform to the latest revision of ASTM Designation: A 276, type 304 (wrought bar stock). The steel shall also conform to the following impurity content requirements on a weight basis:

$$
\begin{aligned}
& \text { Cobalt - } 0.2 \% \text { (max) } \\
& \text { Boron - } 10 \mathrm{ppm} \text { (max) }
\end{aligned}
$$

V. PHYSICAT AND MECHANICAI PROPERTIES:

The physical and mechanical properties shall conform to the requirements of the latest revision of ASTM Designation: A 276 (wrought bar stock), type 304 stainless steel. 
EGCR FUEL ASSEMBLY SPECIFTCATION

METAILURGY DIVISION

OAK RIDGE NATIONAI LABORATORY
Spec. No. EGCR-2-1-2

Date: Nov. I, 1960

Page: 2 of 3

Subject: SPECIFICATION FOR TOP AND BOTPOM END CAPS FOR CORE I FUEL

A.SSEMBLIES FOR THE EXPERTMENTAL GAS-COOLED REACTOR

\section{DIMENSIONAI TOLERANCES:}

The top and bottom end caps shall conform to the dimensions and tolerances specified on Dwg. B-2-02-054-9815-C and in this specification. The critical dimensional tolerances are summarized as follows:

$$
\begin{aligned}
& \text { End cap diameter } \quad 0.712+0.001 \text { in. } \\
& \text { Diameter of end cap projection } \begin{aligned}
0.200 & +0.000 \\
& -0.001
\end{aligned} \text { in. } \\
& \text { Thickness of lip } \quad 0.020 \pm 0.002 \mathrm{in} \text {. } \\
& \text { Height of projection above Iip } \\
& \text { Top end cap } 0.510 \pm 0.003 \text { in. } \\
& \text { Bottom end cap } \quad 0.300 \pm 0.003 \text { in. } \\
& \text { Height of Iip } \quad 0.250+0.000 \text { in. } \\
& \text { Minimum cap thickness dimension } 0.150 \pm 0.005 \text { in. }
\end{aligned}
$$

VII. SURFACE FINISH AND CONDITION:

Surfaces of the top and bottom end caps shall conform to the finishes specified on Dwg. B-2-02-054-9815-C.

All surfaces shall be free of cracks, pits, laps, seams, gouges, and intergranular attack.

Surfaces shall be free of scale, oxide film, dirt, oil, grease, or other foreign material.

VIII. ACCEPTANCE TESTS:

A. Nondestructive

1. Visual. - One hundred percent visual. inspection shall be performed under direct daylight-type fluorescent lighting of at least 100-ft candles to ensure conformance with the requirements of Section VII of this specification.

2. Dimensional. - One hundred percent dimensional inspection shall be performed to ensure conformance to the requirements of Section VI of this specification. Two diametral measurements, 90 deg apart, shall be made of the end cap diameter and on the diameter of the end cap projection. 
EGCR FUEL ASSEMBLY SPECIFICATION

METALLUURGY DIVISION

OAK RIDGE NATIONAI IABORATORY
Spec. No. EGCR-2-1-2

Date: Nov. 1, 1960

Page: 3 of 3

Subject: SPECIFICATION FOR TOP AND BOTIOM END CAPS FOR CORE I FUEL

ASSEMBLIES FOR THE EXPERIMENTAI GAS-COOLED REACTOR

VIII. ACCEPTANCE TESTS (continued):

3. Liquid Penetrant. - One hundred percent liquid-penetrant inspection for discontinuities shall be performed over the entire surface of the finished end caps in accordance with ASTM Designation: E $165-60 \mathrm{~T}$, "Methods for Iiquid-Penetrant Inspection," except as follows:

Precleaning shall be accomplished by vapor degreasing.

"Method A, Procedure A-2" shall be followed except as modified by this specification.

Minimum penetrant soak time shall be $30 \mathrm{~min}$.

Emulsification time shall be held to the minimum required to permit removal of excess penetrant and shall not exceed $3 \mathrm{~min}$.

Drying shall be accomplished by circulating air at $170^{\circ} \mathrm{F}$ or less for a time that will not cause evaporation of penetrant.

Dry-powder developer shall be used. The powder shall remain on the part for a minimum of $10 \mathrm{~min}$ prior to inspection.

Magnaflux ZI 22 penetrant or equivalent shall be used.

"Equivalents" shall be approved by the company.

All penetrant indications shall be investigated. All discontinuities detected by penetrant inspection shall be removed. Caps must comply with dimensional tolerances after the indications have been removed.

Reinspection after removal of defects is required.

B. Destructive

The bar stock from which the end caps are fabricated shall be sampled in accordance with the latest revision of ASTM Designation: A 276 for use in chemical analysis and physical tests to assure conformance of the finished pieces with sections IV, V, and VII of this specification.

IX: TEST REPORTS:

Four certified copies of test reports shall be furnished by the seller to the company at the time of shipment. At the time of shipment, the seller shall also furnish to the company four copies of a certification stating that all requirements of this specification have been met. 
EGCR FUEL ASSEMBLY SPECIFICATION METALLURGY DIVISION

OAK RIDGE INATIONAL LABORATORY

Spec. No. EGCR-2-1-3

Date: Nov. I, 1960

Union Carbide Nuclear Company

A Division of Union Carbide Corporation

Oak Ridge, Tennessee

\begin{abstract}
Subject: SPECIFICATION FOR URANIUM DIOXIDE FUEL PEILETS FOR CORE I FUEL
ASSEMBLIES FOR THE EXPERIMENTAL GAS-COOLED REACTOR
\end{abstract}

\title{
I. SCOPE:
}

This specification defines hollow fuel pellets made of uranium dioxide. The pellets are approx 3/4 in. long, 0.7-in.-0.d. with ani0.2-in. wall thickness and are dished at each end to a depth of 0.005 in. as shown in the referenced drawing. The pellets shall be furnished in enrichments of approx 2.2\%, 2.4\%, and 2.6\%. A total of approx 3700013 of $\mathrm{UO}_{2}$ pellets are required.

The $\mathrm{UO}_{2}$ pellets shall be furnished in stacks consisting of $36 \mathrm{UO}_{2}$ pellets and two magnesia insulators, one at each end of the stack.

II. MATERTALS:

The company shall supply to the seller the uranium hexafluoride to complete the full core loading (45 500 Ib UF6) plus a 5\% surolus (2300 13 UF6).

The seller shall pay for all uranium metal losses exceeding $1 \%$ of the total quantity processed; ioe., any uranium metal losses exceeding approx $325 \mathrm{Ib}$.

The seller shall pay the cost of reprocessing all scrap material to UF6, including the cost of shipping.

The uranium hexafluoride will be enriched to the specified amounts $\pm 0.013 \%$ by weight in $\mathrm{U}^{235}$. The seller's conversion and fabrication processes sha.1. be such that the isotopic composition of the finished. uranium dioxide fuel pellets shall not differ from that of the uranium hexafluoride by more than $1.5 \%$ of the contained amount.

III. REFERENCE:

Dwg. B-2-02-054-9820-B, "UO2 Pellet"

TID - 7015, Section I, "ORNL Master Analytical Manual"*

Analytical Chemistry, 32, 610 (1960), "Determination of o/U Ratio in $\mathrm{UO}_{2}$, $\mathrm{H}$. Kubota

*This document is available from the offices of Technical Services, Depart of Commerce, Washington 25, D. C. 
EGCR FUEL ASSEMBLY SPECIFICATION METAILIURGY DIVISION

OAK RIDGE NATIONAL LABORATORY
Spec. No. EGCR-2-1-3

Date: Nov. I, 1960

Page: 2 of 8

Subject: SPECIFICATION FOR URANTUM DIOXIDE FUEI, PELIETS FOR CORE I FUEL ASSEMBLIES FOR THE EXPERIMENTAL GAS-COOLED REACTOR

IV. MANUFACTURING REQUTREMENTS:

The uranium dioxide pellets shall be manufactured in accordance with

Dwg. B-2-02-054-9820-A, "UO 2 Pellet," and with this specification.

V. CHEMICAL COMPOSTTION:

The finished fuel pellets shall conform to the following chemical analysis:

$\begin{aligned} \text { Total Uranium } & \text { Not less than } 88.0 \text { wt } \% \\ \text { Carbon } & 500 \mathrm{ppm} \text { (max) } \\ \text { Nitrogen } & 500 \mathrm{ppm} \text { (max) } \\ \text { Calcium } & 100 \mathrm{ppm} \text { (max) } \\ \text { Aluminum } & 100 \mathrm{ppm} \text { (max) } \\ \text { Silicon } & 100 \mathrm{ppm} \text { (max) }\end{aligned}$

The sum of the following impurities shall not exceed the equivalent thermal-neutron capture cross section of 20 ppm of boron:

$\begin{aligned} \text { Boron } & \text { Gadolinium } \\ \text { Cadmium } & \text { Europium } \\ \text { Silver } & \text { Samarium }\end{aligned}$

A coefficient of boron equivalent ( $\mathrm{CBE}$ ) may be calculated for the above elements as follows:

$$
\mathrm{CBE}=\frac{\text { (atomic welght boron }) \times\left(\sigma_{a} \text { impurity }\right)}{\text { (atomic weight impurity }) \times\left(\sigma_{a} \text { boron }\right)}
$$

$\sigma_{8}$ is defined as: thermal-neutron absorption cross section.

The following list contains boron equivalent coefficients for the high cross-section impurities listed above:

$\begin{aligned} \text { Boron } & 1.0 \\ \text { Silver } & 8.9 \times 10^{-3} \\ \text { Cadmium } & 0.325 \\ \text { Gadolinium } & 4.191 \\ \text { Europium } & 0.434 \\ \text { Samarium } & 0.524\end{aligned}$

The oxygen-to-uranium ratio of the finished fuel pellets shall be within the range 2.00 to 2.02 .

VI. DEMSITY:

The minimum bulk density of the fuel pellet shall be $94 \%$ of theoretical density for uranium-dioxide bodies. Using a theoretical density of $10.96 \mathrm{~g} / \mathrm{cm}^{3}$, the minimum bulk density of the fuel pellet shall be $10.30 \mathrm{~g} / \mathrm{cm}^{3}$. 
EGCR FUEL ASSEMBLY SPECIFICATION

METALIURGY DIVISION

OAK RIDGE NATIONAL LABORATORY
Spec. No. EGCR $-2-1-3$

Date: Nov. I, 1960

Page: $\frac{3 \text { of } 8}{8}$

Subject: SPECIFICATION FOR URANIUM DIOXIDE FUEL PELIETS FOR CORE I FUEL ASSEMBLIES FOR THE EXPERTMENTAL GAS-COOLED REACTOR

VII. DIMENSIONAE:

The fuel pellet shall conform to the following dimensional tolerances:

$$
\begin{array}{ll}
\text { Outside diameter } & 0.707 \pm 0.001 \text { in. } \\
\text { Inside diameter } & 0.323 \pm 0.005 \text { in. } \\
\text { Wall thickness } & 0.192 \pm 0.015 \mathrm{in} . \\
\text { Length } & 0.740 \text { nominal } \\
\text { Major diameter of } & 0.600 \pm 0.005 \mathrm{in} . \\
\text { dished area } & \\
\begin{array}{l}
\text { Depth of dished area } \\
\text { at inside diameter }
\end{array} & \\
\text { of pellet } & 0.005 \pm 0.002 \mathrm{in} .
\end{array}
$$

Each fuel pellet face shall be perpendicular with the fuel pellet outside surface within 0.005 in., except for the dished area on each end.

The total length of the column of uranium dioxide fuel pellets shall be

$$
26.625 \text { in. }^{+}+0.000 \text { in. }
$$

The total length of the column of uranium dioxide fuel pellets and the two magnesia pellets (one at each end of the stack) shall be $27.000 \pm 0.010 \mathrm{in}$. To achieve the narrower length tolerance, the magnesia pellets shall be in four thicknesses for selectivity.

VIII. DRYNESS:

The finished pellets shall be sufficiently dry so that when heated for 4 hr under vacuum at $250^{\circ} \mathrm{C}$, the weight loss shall not exceed $10 \mathrm{ppm}$. The pressure inside the oven shall not exceed $1000 \mu$.

IX。 WEIGHT:

The weight of each stacked length of fuel pellets shall be I4II $\pm 33 \mathrm{~g}$.

X. SURFACE FINISH AND CONDITION:

\section{A. Chipping}

Chipping on the outside cylindrical surface shall not exceed 10\% of the outside cylindrical surface area. Chipping on each end of the pellet shall not exceed $25 \%$ of the surface area of one end of the pellet. No chip shall be greater than $1 / 8$ in. in lateral dimension nor greater than $1 / 32$ in. in depth.

The cylindrical surface on the inside diameter shall not be inspected for chipping. 
EGCR FUEL ASSEMBLY SPECIFICATION

Spec. No. EGCR-2-1-3

METALLURGY DIVISION

OAK RIDGE NATIONAI LABORATORY

Date: Nov: 1,1960

Page: 4 of 8

\section{Subject: SPECIFICATION FOR URANIUM DIOXTDE FUEL PELIETS FOR CORE I FUEL ASSEMBLIES FOR THE EXPERIMENTAI GAS-COOLED REACIOR}

\footnotetext{
X. SURFACE FINISH AND CONDITION (continued):

B. Cracks

Radial cracks exceeding $25 \%$ of the wall thickness shall be cause for rejection. Radial cracks are defined as cracks observed at the end or ends of the pellet which are in a radial direction.

Circumferential cracks shall be cause for rejection if the crack is continuous over an arc of $45 \mathrm{deg}$ or more. A circumferential crack is defined as a crack observed at the end of the pellet or on the circumferential surface and running parallel to the circumference or perpendicular to a radial direction.

C. Sponginess or Microcracking

Excessive sponginess or microcracking, as illustrated in Fig. 4 , shall be cause for rejection.

D. Visual Standards

Two groups of pellets typical of production quality shall be mutually selected by the seller and the company for use as visual standards. The two groups shall be duplicates as nearly as is practical. One group shall be retained by the sellex and one by the company. These pellets shall include the types of defects to be expected during manufacture of the core loading and will be labeled "acceptable" or "unacceptable" "The seller"s group of pellets, or visual standards, shall be used as guides during visual inspection for surface finish and condition.
}

XI. ACCEPTANCE TESTS:

A. Nondestructive

1. Visual. - The fuel pellets shall be subjected to $100 \%$ visual. inspection to assure conformance with section $X$ of this specification. The inspection shall be performed under direct daylighttype fluorescent 11lumination of at least 100-ft candles.

2. Dimensional. - One percent of each day ${ }^{3} \mathrm{~s}$ grinding of pellets, randomly selected, shall be dimensionally inspected to assure conformance to Section VII of this specification. If any of these pellets do not meet dimensional tolerances, the entire day ${ }^{3}$ grinding production shall be $100 \%$ dimensionally inspected.

Each stacked column of $\mathrm{VO}_{2}$ shall be measured for length and weighed to assure conformance to specified stack length and weight as specified in Sections VII and IX, respectively, of this specification. 


\section{EGCR FUEL ASSEMBLY SPECIFICATION \\ METALIURGY DIVISTON \\ OAK RIDGE NATIONAL IABORATORY}

Spec. No. EGCR-2-1-3

Date: Nov. 1,1960

Page: 5 of 8

Subject: SPECIFICATION FOR URANIUM DIOXIDE FUEL PELLETS FOR CORE I FUEL ASSEMBLIES FOR THE EXPERIMENTAL GAS-COOLED REACTOR

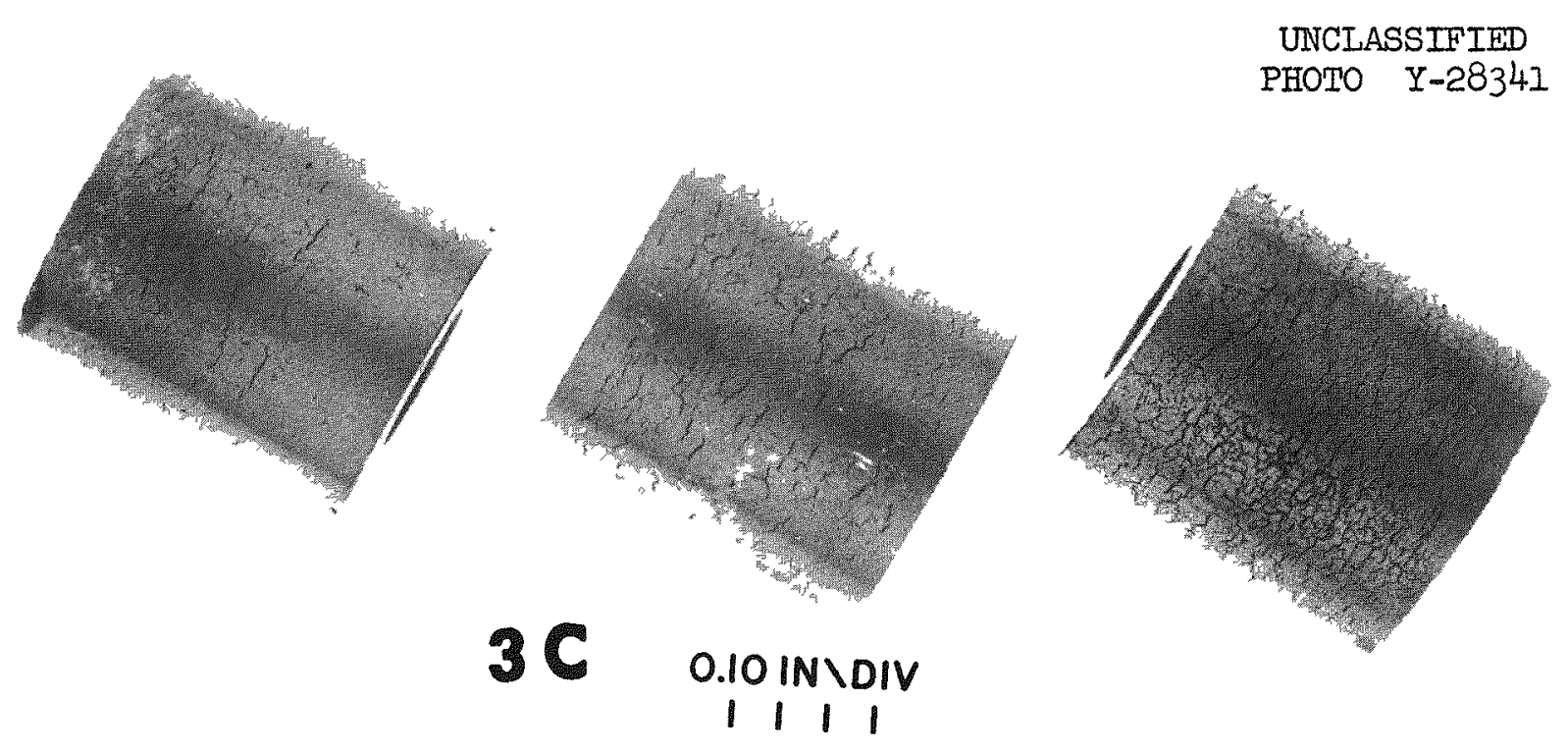

Fig. 4. Photograph of UO2 Fuel Pellets Illustrating Excessive Sponginess and Microcracking. The pellet on the left is acceptable. The pellet on the right in the photograph is unacceptable. The pellet in the center is borderline but is also unacceptable. 


\section{EGCR FUEL ASSEMBLY SPECIFICATION METALLURGY DIVISTON \\ OAK RIDGE NATIONAI LABORATORY}

Spec. No. EGCR-2-1-3

Date: Nov. I, 1960

Page: 6 of 8

Subject: SPECIFICATION FOR URANIUM DIOXIDE FUEL PELIETS FOR CORE I FUEL ASSEMBLIES FOR THE EXPERIMENTAL GAS-COOLED REACTOR

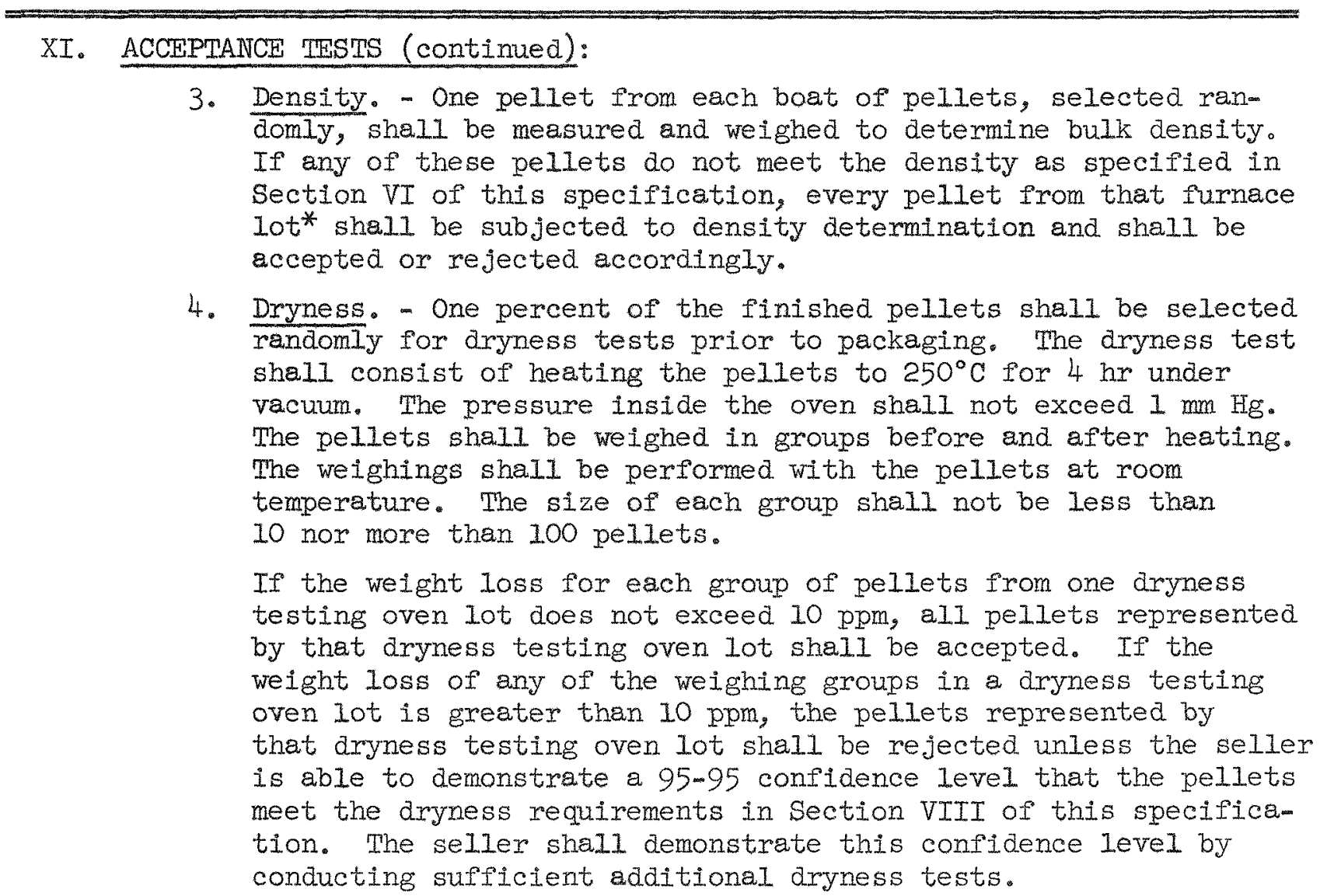

B. Destructive

1. Oxygen/Uranium Ratio, Total Uranium, Carbon, and Hitrogen. -

a. Sampling: Two pellets shall be selected randomly from each furnace lot ${ }^{*}$ for determinations for oxygen/uranium ratio, total uranium, carbon, and nitrogen. At least one oxygen/ uranium ratio and total uranium analysis shall be performed. on each of the two pellets. Duplicate samples from each of these pellets shall be sent to the company for testing.

${ }^{*}$ A furnace lot is that quantity of pellets that are in the sintering zone of the furnace at one time. 
Subject: SPECIFICATION FOR URANIUM DIOXIDE FUEL PEILEIS FOR CORE I FUEL ASSEMBLIES FOR THE EXPERTMENTAL GAS-COOLED REACTOR

\footnotetext{
XI. ACCEPTANCE TESTS (continued):

b. Method of Analysis: The oxygen/uranium ratio shall be determined by the polarographic method according to the procedure described in section III-3 of this specification or by an approved alternate method.

Total uranium shall be determined by the potentiometric or volumetric methods according to procedures recommended by the company* or by an approved alternate method.

c. Qualification of Seller's Analytical Procedure: Standard. samples will be furnished to the seller by the company for qualification of the sellex"s analytical procedure. This qualification shall be prerequisite to committing the UF6 to manufacture.

d. Acceptance or Rejection: If the oxygen/uranium ratio; and total uranium content do not meet the requirements specified in Section $V$ of this specification, the entire furnace lot of sintered pellets shall be rejected unless the seller performs additional analyses sufficient to assure a 95-95\% confidence level that the pellets are within the limits specified.

2. Isotopic and Impurity Analyses. -

a. Sampling: One finished pellet representing each blending batch** of $\mathrm{UO}_{2}$ powder shall be selected randomly for isotopic and impurity analyses. The pellet shall be selected from pellets that have been ground to size, washed, and dried. Duplicate samples shall be sent to the company for testing.

*Three suitable methods for the determination of the uranium content of $\mathrm{UO}_{2}$ are found in the ORNL Master Analytical Manual, published as TID - 7015, Section I. The methods are: No. 900719270, Uranium, Volumetric Zinc AmaIgamPotassium Dichromate Method. No. 900719222, Uranium, Potentiometric Ferric Sulfate Method.

No. 900719224, Uranium, Automatic Potentiometric Ferric Sulfate Methods

**A blending batch is defined as that quantity of $\mathrm{UO}_{2}$ powder that is blended together so that the chemical and isotopic composition may be assumed to be nearly identical.
} 
EGCR FUEL ASSEMBLY SPECIFICATION

METALIUURGY DIVISION

OAK RIDGE NATIONAI LABORATORY
Spec. No. EGCR-2-1-3

Date: Nov. 1,1960

Page: $\frac{8}{8}$ of

Subject: SPECIFICATION FOR URANIUM DIOXTDE FUEL PELIETS FOR CORE I FUEL

ASSEMBLIES FOR THE EXPERIMENTAL GAS-COOLED REACTOR.

\section{ACCEPTANCE TESTS (continued):}

b. Acceptance or Rejection: If the isotopic and impurity analyses do not conform to the limits specified in Sections II and $V$, respectively, of this specification, all the pellets fabricated from that entire batch of powder shall. be rejected unless the seller performs additional analyses sufficient to assure a 95-95\% confidence level that the pellets are within the limits specified.

XII. TEST REPORTS:

Four certified copies of dryness test reports shall be furnished to the company prior to encapsulation of the pellets. Four copies of certified chemical analyses for oxygen/uranium ratio and total uranium and density determinations shall be furnished for each furnace lot of sintered pellets. The analyses and density determinations shall be performed as described in Section XI-B-I of this specification.

Four copies of certified chemical analyses for impurities and isotopic analysis for U235 content shall be furnished to the company prior to shipment for one pellet from each blended batch of $\mathrm{UO}_{2}$ powder.

The seller shall furnish to the company prior to encapsulation of the pellets four copies of a certification stating that all requirements of this specification have been met.

XIII. SAMPLE PEILETS:

Two finished pellets representing each blending batch of material shall be furnished to the company for evaluation purposes.

XIV. PACKING AND SHIPPING:

Each stacked column of fuel along with top and bottom magnesium oxide pellets shall be inserted into a length of type 304 stainless steel fuel capsule tubing with the cap already welded into the bottom end. The top end of the tubing shall be sealed with a plastic cap or a similar device that will prevent contamination of the area to be welded. The entire length of tubing shall be sealed in an individual moisture proof container containing a desiccant. The tube shall be clearly marked to identify the enrichment of fuel contained therein. The marking shall be temporary such as a nonsulfur-bearing ink or a sticker. 
EGCR FUEL ASSEMBLY SPECIFICATION METALLURGY DIVISION

OAK RIDGE NATIONAL IABORATORY

Union Carbide Nuclear Company

A Division of Union Carbide Corporation

Oak Ridge, Tennessee
Spec. No. EGCR-2-1-4 Date: Nov. 1, 1960

Page: 1 of 2

\section{Subject: SPECIFICATION FOR MAGNESIUM OXIDE PELIETS FOR CORE I FUEL ASSEMBLIES FOR THE EXPERIMENIAL GAS-COOLED REACTOR}

\section{SCOPE:}

This specification defines magnesium oxide pellets $0.7 \mathrm{in}$. in diameter. The pellets shall be in four thicknesses of approx $3 / 16$ in.

\section{MANUFACTURING REQUIREMENTS:}

The magnesium oxide pellets shall be manufactured in accordance with Dwg. B-2-02-054-9819-B and with this specification.

ITI. REFERENCES:

Dwg. B-2-02-054-9819-B, "Magnesium Oxide Pellet"

IV. CHEMICAL COMPOSTTION:

The material shall conform to the following analysis:

$\begin{array}{ll}\mathrm{SiO}_{2} & 0.2 \text { wt } \% \text { (max) } \\ \mathrm{Fe} & 0.1 \text { wt } \% \text { (max) } \\ \mathrm{Al}_{2} \mathrm{O}_{3} & 0.35 \text { wt } \% \text { (max) } \\ \mathrm{CaO}^{2} & 0.2 \text { wt } \% \text { (max) } \\ \mathrm{B} & 20 \text { ppm (max) } \\ \mathrm{MgO} & \text { Remainder }\end{array}$

V. DENSTTY:

The pellets shall be sintered to a density of $2.6 \pm 0.6 \mathrm{~g} / \mathrm{cc}$.

VI. DIMENSIONAI, TOLERANCES:

Diameter

$0.705 \pm 0.003$ in.

Thickness (The pellets shall be furnished in four thicknesses.)

$$
\begin{aligned}
\text { 1. } 0.188 & +0.000 \text { in. } \\
\text { 2. } 0.005 & +0.000 \text { in. } \\
\text { 3. } 0.208 & +0.005 \text { in. } \\
& -0.005 \text { in. } \\
\text { 4. } 0.218 & +0.000 \text { in. } \\
& =0.005 \text { in. }
\end{aligned}
$$


EGCR FUEL ASSEMBLY SPECIFICATION METAILURGY DIVISION

OAK RIDGE NATIONAL LABORATORY
Spec. No. EGCR-2-1-4

Date: Nov. I, 1960

Page: 2 of 2

\section{Subject: SPECIFICATION FOR MAGNESIUM OXIDE PEILETS FOR CORE I FUEL}

ASSEMBLIES FOR THE EXPERIMENTAL GAS-COOLED REACTOR

\section{CLEANLINESS:}

The pellets shall be clean and free of moisture, dirt, grease, oil, or fabrication lubricants.

VIII. SURFACE CONDITION:

The surfaces shall be free of cracking or chipping as determined by visual inspection.

IX. TTEST REPORTS:

The sellex shall furnish to the company four copies of certified chemical analyses of finished pellets. At the time of shipment, the seller shall also furnish to the company four copies of a certification stating that all requirements of this specification have been met. 
EGCR FUEL ASSEMBLY SPECIFICATION METALLURGY DIVISION

OAK RIDGE NATIONAL LABORATORY

Union Carbide Nuclear Company

A Division of Union Carbide Corporation

Oak Ridge, Tennessee
Spec. No. EGCR-2-1-5

Date: Nov. I, 1960

Page: 1 of 3

Subject: SPECIFICATION FOR FUEL FLEMENT SPACERS FOR CORE I FUEI ASSEMBLIES

FOR THE EXPERTMENTAL GAS-COOLED REACTOR

I. SCOPE:

This specification defines spacexs for fuel elements for the Experimental Gas-Cooled Reactor. The spacers are made of type 304 stainless steel.

II. MANUFACTURING REQUIREMENTS:

The spacers shall be manufactured in accordance with Dwg. B-2-02-0549817-D and as outlined in this specification.

The spacers may be fabricated by casting or from wrought bar stock.

III. REFERENCES:

Dwg. B-2-02-054-9817-D, "Fuel. Element Spacers"

ASTM Designation: A 276 - 57 T, "Specification for Hot-Rolled and ColdFinished Corrosion-Resisting Steel Bars"

ASTM Designation: A 351 - 58 T, "Tentative Specifications for Ferritic and Austenitic Steel Castings for High Temperature Service"

ASTM Designation: E 165 - 60 T, "Methods for Liquid Penetrant Inspection"

ASTM Designation: E 142 - 59 T, "Tentative Method for Controlling Quality of Radiographic Testing"

IV. CHEMICAL COMPOSITION:

The chemical composition shall conform to the latest revision of ASTM Designation: A 276, type 304 (wrought bar stock) or ASTM Designation: A 351, grade CF 8, respectively. The steel shall also conform to the following impurity content requirements on a weight basis:

$$
\begin{aligned}
& \text { Cobalt }-0.2 \%(\max ) \\
& \text { Boron - } 10 \mathrm{ppm}(\max )
\end{aligned}
$$

V. PHYSICAI AND MECHANICAL PROPERTIES:

Depending upon the method of fabrication, the physical and mechanical properties shall conform to the requirements of the latest revision of ASTM Designation: A 276 (wrought bar stock) or ASIM Designation: A 351, grade CF 8, respectively. 
Subject: SPECIFICATION FOR FUEL ELEMENT SPACERS FOR CORE I FUEL ASSEMBIIES FOR THE EXPERTMENTAI GAS-COOLED REACTOR

\footnotetext{
VI. DIMENSIONAL TOLERANCES:

The spacer shall conform to the dimensions and tolerances specified on Dwg. B-2-02-054-9817-D.

VII. SURFACE FINISH AND CONDITTON:

Surfaces of the spacer shall conform to the finishes specified on Dwg. B-2-02-054-9817-D. All surfaces shall be free of scale, oxide film, dirt, oil, grease, or other foreign material. Surfaces shall also be free of cracks, laps, seams, gouges, and intergranular attack.
}

VIII. ACCEPTANCE TESTS:

A. Nondestructive

1. Visual. - One hundred percent visual inspection shall be performed under daylight-type fluorescent lighting of at least 100-ft candles to ensure conformance with the requirements of Section. VII of this specification.

2. Radiography. - Radiography is not required if the spacers are manufactured from wrought bar stock.

If the spacers are cast, radiographic inspection shall be performed on each piece in accordance with the latest revision of ASTM Designation: $\mathrm{E} 142$.

The level of radiography in the pad of the spacer shall be at least equivalent to $2-2 \mathrm{~T}$; i.e., a penetrameter providing $2 \%$ contrast sensitivity shall be present in each film. Thus, the penetrameter shall be $2 \%$ of the spacer thickness (0.005 in.) and shall contain a 21 - diam hole ( 0.010 in.)

Multiple parts may be placed on the same film.

3. Dimensional. - One hundred percent dimensional inspection shall be performed to assure conformance with section VI of this specification.

4. Liquid Penetrant. - A Iiquid-penetrant inspection for Iineartype discontinuities shall be performed over the entire surface of $100 \%$ of the finished spacers in accordance with ASTM Designation: E 165 - $60 \mathrm{~T}$, "Methods for Liquid Penetrant Inspection," except as follows:

Precleaning shall be accomplished by vapor degreasing.

- "Method A, Procedure A-2" shall be followed except as modified by this specification. 


\section{EGCR FUEL ASSEMBLY SPECIFICATION METALLURGY DIVISION \\ OAK RIDGE NATIONAL IABORATORY}

Spec. No. EGCR-2-1-5

Date: Nov. I, 1960

Page:

\section{Subject: SPECIFICATION FOR FUEL ELEMENT SPACERS FOR CORE I FUEL ASSEMBLIES FOR THE EXPERIMENTAL GAS-COOLED REACTOR}

VIII. ACCEPTANCE TESTS (continued):

Minimum penetrant soak time shall be 30 min.

Emulsification time shall be held to the minimum required to permit removal of excess penetrant and shall not exceed 3 min. Drying shall be accomplished by circulating air at $170^{\circ} \mathrm{F}$ or less for a time that will not cause evaporation of penetrant. A dry-powder developer shall be used. The powder shall remain on the part for a minimum of $10 \mathrm{~min}$ prior to inspection. Magnaflux ZL 22 penetrant or equivalent shall be used. "Equivalents" shall be approved by the company.

All indications shall be evaluated by visual means in accordance with section VIII-A-I of this specification.

B. Destructive

Chemical analysis, physical testing, and metallographic examination shall be performed in accordance with the latest revision of ASTM Designation: A 276 to assure conformance of the finished pieces with Sections IV and $V$ of this specification.

IX. TEST REPORTS:

Four certified copies of the test reports shall be furnished by the seller to the company at time of shipment. At the time of shipment, the seller shall also furnish to the company four copies of a certification stating that all requirements of this specification have been met. 
EGCR FUEL ASSEMBLY SPECIFICATION

METALLURGY DIVISION

OAK RIDGE NATIONAL LABORATORY

Union Carbide Nuclear Company

A Division of Union Carbide Corporation

oak Ridge, Temnessee
Spec. No. EGCR-2-2

Date: Nov. 1,1960

Page: 1 of 5

Subject: SPECIFICATION FOR TOP SPIDERS AND LOWER SPIDERS FOR CORE I FUEL ASSEMBLIES FOR THE EXPERIMENTAL GAS-COOLED REACTOR

I. SCOPE:

This specification defines type 304 stainless steel top spiders and lower spiders.

II. MANUFACIURING REQUIREMENTS:

The top spiders and Iower spiders shall be manufactured in strict conformance with Dwgs. $B-2-02-054-9814-D$ and $B-2-02-054-9816-B$, respectively, and with this specification.

The top spiders and lower spiders shall be manufactured by investment casting and ma,chining where necessary to final dimensions.

III. REFERENCES:

ASTM Designation: A 351 - 58 T, "Tentative Specifications for Ferritic and Austenitic Steel Castings for High Temperature Service"

Dwg. B-2-02-054-9814-D, "Top Spider"

Dwg. B-2-02-054-9816-B, "Lower Spider"

ASTM Designation: A 370, "Methods and Definitions for Mechanical Testing of Steel Products"

ASTM Designation: E 165 - 60 T, "Method for Liquid Penetrant Inspection"

ASTM Designation: E 142 - 59 T, "Tentative Method for Controlling Quality of Radiographic Testing"

IV. CHEMICAI COMPOSTTION:

The chemical composition of the austenitic stainless steel used shall conform to the requirements of the latest edition of ASTM Designation: A 351 - 58 T, grade CF 8. The steel shall also conform to the following impurity requirements on a weight basis:

$$
\begin{array}{ll}
\text { Cobalt } & 0.2 \%(\max ) \\
\text { Boron } & 10 \mathrm{ppm}(\max )
\end{array}
$$

V. PHYSICAL PROPERTIES:

The physical properties of the austenitic stainless steel used shall. conform to the requirements of the latest edition of ASTM Designation: A 351, grade CF 8 . 
EGCR FUEL ASSEMBLY SPECTFTCATION

METALEURGY DIVISION

OAK RIDGE NATIONAL IAABORATORY
Spec. No. EGCR-2-2

Date: Nov. I, 1960

Page: $\frac{\text { of } 5}{2}$

Subject: SPECIFICATION FOR TOP SPIDERS AND LOWER SPIDERS FOR CORE I FUEL ASSEMBLIES FOR THE EXPERTMEIVTAL GAS-COOLED REACTOR

VI. MECHANICAI PROPERTIES:

The mechanical properties of the austenitic stainless steel used shall conform to the requirements of the latest edition of ASTM Designation: A 351, grade CF 8.

VII. DIMENSIONAL TOLERANCES:

The top spider shall conform strictly to the dimensions and tolerances specified in Dwg. B-2-02-054-9814-D. The lower spider shall conform strictly to the dimensions and tolerances specified in Dwg. B-2-02-0549816-B.

A summary of the critical tolerances is presented below:

Radial positioning of holes

Diameter of holes

Perpendicularity of holes with respect to bottom of casting

Width of positioning projections

Angular location of positioning projections:

Top spider

Lower spider

$$
\begin{aligned}
0.993 \pm 0.001 \text { in. } & \\
0.201+0.001 & \text { in. } \\
& =0.000
\end{aligned}
$$$$
90 \pm 0 \mathrm{deg}, 5 \mathrm{~min}
$$$$
0.115+0.000 \text { in. }
$$

$90 \pm 0 \mathrm{deg}, 5 \mathrm{~min}$

$60 \pm 0$ deg, $5 \mathrm{~min}$

VIII. SURFACE FINISH AND CONDITION:

The surfaces of the top spider and lower spider shall conform to the finishes specified on Dwgs. B-02-054-9814-D and B-2-02-054-9816-B, respectively.

The surfaces shall be free of cracks, laps, and gouges. Surface pits shall be no greater than $10 \%$ of the web thickness, as determined by visual examination.

The surface shall be free of scale, oxide film dirt, oil, grease, or other foreign material as determined by visual inspection.

IX. ACCEPTANCE TESTS:

A. Nondestructive

1. Dimensional. - Each finished top spider and lower spider shall be subjected to dimensional inspection to assure that it conforms dimensionally to the drawing. The method of inspection to the above specified dimensions shall be approved by the company. 
EGCR FUEL ASSEMBLY SPECIFICATION

METALLURGY DIVISION

OAK RIDGE NATIONAL LABORATORY
Spec. No. EGCR-2-2

Date: Nov. 1,1960

Page: 3 of 5

\section{Subject: SPECIFICATION FOR TOP SPIDERS AND LOWER SPIDERS FOR CORE I FUEL ASSEMBLIES FOR THE EXPERTMENTAL GAS-COOLED REACTOR}
IX. ACCEPTANCE TESTS (continued):
2. Visual. - Each finished top spider and lower spider shall be subjected to visual inspection to assure conformance to Section VIII of this specification. Inspection is to be per- formed under direct daylight-type fluorescent illumination of at least 100-ft candles.

3. Liquid Penetrant. - A Iiquid-penetrant inspection for Iineartype discontinuities shall be performed over the entire surface of $100 \%$ of the finished spiders in accordance with recommendations of ASTM Designation: E $165-60$ T, "Methods for Liquid Penetrant Inspection," except as follows:

a. Precleaning shall be accomplished by vapor degreasing.

b. "Method A, Procedure A-2" of ASTM Designation: E 165 - $60 \mathrm{~T}$ shall be followed except as modified by this specification.

c. Minimum penetrant soak time shall be 30 min.

a. Emulsification time shall be held to minimum required to permit removal of excess penetrant and shall not exceed. 3 min.

e. Drying shall be accomplished by circulating air at $170^{\circ} \mathrm{F}$ or less for a period of time that will not cause evaporation of penetrant.

f. Dry-powder developer shall be used. The powder shall remain on the part a minimum of 10 min prior to inspection.

g. Magnaflux ZL 22 penetrant, or equivalent, shall be used. The "equivalents" shall be approved by the company.

h. AII linear discontinuities detected by penetrant inspection may be removed. Reinspection after removal of defects is required.

4. Radiography. - Radiographic inspection shall be performed according to the following sampling plan:

One hundred percent inspection shall be performed on the first 25 top spider castings and the first 25 lower spider castings. If none of the castings are rejected due to radiographic defects, the sampling shall be reduced to every fourth casting. If one or more of the first 25 castings are rejected due to radiographic examination, the $100 \%$ inspection shall be continued until 25 castings have been examined consecutively without rejection. 
EGCR FUEL ASSEMBLY SPECIFICATION

METALIURGY DIVISION

OAK RIDGE NATIONAL LABORATORY
Spec. No. EGCR-2-2

Date: Nov. I, 1960

Page: 4 of 5

Subject: SPECIFICATION FOR TOP SPIDERS AND LOWER SPIDERS FOR CORE I FUEL ASSEMBLIES FOR THE EXPERTMENTAL GAS-COOLED REACTOR

IX. ACCEPTANCE TESTS (continued):

At that time, the sampling shall be reduced to every fourth casting. If radiographic examination then reveals defects in any of these castings, sampling shall revert to the original cycle; i.e., 25 consecutive castings shall be radiographed.

A casting shall be rejected if radiographic examination reveals porosity that reduces the metal thickness by $10 \%$.

Radiographic inspection shall be performed in accordance with ASIM Designation: E 142 - 59 T at a level of 2-2T in the truncated cones of the castings. Multiple parts may be placed on the same film.

All castings which are radiographed shall be identified as shall the radiographic film so that a permanent record of all inspected castings may be kept. Radiographs are to become the property of the company.

B. Destructive

1. Chemical Analysis. - An analysis of each heat of steel shall be made to determine the percentages of the elements prescribed in Section IV of this specification. This analysis shall be made from drillings taken not less than $1 / 4$ in. beneath the surface of a test ingot obtained during the pouring of the heat. The chemical composition thus determined shall be reported to the company and shall conform to the requirements described in Section IV of this specification.

2. Tensile Tests. - One tension test shall be made from each heat in each heat-treatment charge. Test specimens shall be prepared. and tension tests shall be performed in accordance with ASTM Designation: A 370, "Methods and Definitions for Mechanical Testing of Steel Products."

3. Metallographic Examination. - Metallographic examination at 100X shall be made of sections of five top spiders and five lower spiders selected at random. These examinations shall show the structure to be free from intergranular attack. If intergranular attack is present in any of the specimens, the entire lot of splders shall be rejected unless the seller performs sufficient additional examinations to assure that $95 \%$ of the spiders are free of intergranular attack $95 \%$ of the time. The metallographic specimens shall be identified as to heat number and furnished to the company at time of shipment of the finished parts. 
EGCR FUEL ASSEMBLY SPECIFICATION

METALLURGY DIVISION

OAK RIDGE NATIONAI IABORATORY
Spec. No. EGCR-2-2

Date: Nov。 $\overline{1,1960}$

Pa.ge: $\frac{5 \text { of } 5}{5}$

Subject: SPECIFICATION FOR TOP SPIDERS AND LOWER SPIDERS FOR CORE I FUEL ASSEMBLIES FOR THE EXPERIMENTAL GAS-COOLED RFACTOR

X. TEST REPORTS:

Four certified copies of test reports and photomicrographs of metallographic sections shall be furnished by the seller to the company at the time of each shipment. At the time of shipment, the seller shall also furnish to the company four copies of a certification stating that all requirements of this specification have been met. 
EGCR FUEL ASSEMBIY SPECIFICATION

METALIURGY DIVISION

OAK RIDGE NATIONAL LABORATORY

Union Carbide Nuclear Company

A Division of Union Carbide Corporation

Oak Ridge, Tennessee
Spec。 No. EGCR-2-3

Date: Nov. I, 1960

Page: 1 of 4

Subject: SPECIFICATION FOR GRAPHITE SUPPORT SLEEVES FOR CORE I FUEL

ASSEMBLIES FOR THE EXPERIMENTTAL GAS-COOLED REACTOR

\section{SCOPE:}

This specification defines nuclear-grade, graphite support sleeves. The sleeves are approx 29 in. Iong, approx 5-in.-outside diameter, and 3-in.inside diameter. The sleeves are a structural component of the fuel assembly and are used to house a seven-rod fuel element cluster.

II. MANUFACTURING REQUIREMENTS:

The graphite support sleeves shall be manufactured in accordance with Dwg。 D-2-02-054-9812-C and with this specification.

A. Materials

The material used for the sleeves shall be nuclear-grade graphite. The graphite sha.l be manufactured from a coke having a needle-type structure.

B. Manufacturing Process

The graphitizing temperature shall be not less than $2800^{\circ} \mathrm{C}$. No Freon or chdorination treatment is required. Nuclear quality is to be assured by the proper selection of base materials and use of a graphitizing temperature sufficiently high to remove inherent impurities by volatilization.

The manufacturing process shall be such that the lamination lines shall not be exposed on the cylindrical surface during subsequent machining。

III. REFERENCES:

Dwg. D-2-02-054-9812-C, "Support Sleeve"

ASTM Designation: C $190-58$, "Tensile Strength of Hydraulic Cement Mortars"

ASTM Designation: C 78 - 57, "Test for Flexural Strength of Concrete (using simple beam with third-point loading)"

IV. PHYSICAL PROPERIIES:

A. Graphite Density

Finished machined graphite conforming to this specification shall have a minimum average density for all support sleeves of $1.65 \mathrm{~g} / \mathrm{cm}^{3}$. The minimum acceptable density in any one graphite support sleeve sha.1 1 be $1.60 \mathrm{~g} / \mathrm{cm}^{3}$. 
EGCR FUEL ASSEMBLY SPECIFICATION

METALIURGY DTVISION

OAK RIDGE NATIONAI LABORATORY
Spec. No. EGCR-2-3

Date: Nov. 1,1960

Page: 2 of 4

Subject: SPECIFICATION FOR GRAPHITE SUPPORT SLEEVES FOR CORE I FUEL

ASSEMBLIES FOR THE EXPERIMENTAL GAS-COOLED REACTOR

\begin{abstract}
IV. PHYSICAL PROPERTIES (continued):
B. Nuclear Properties

The nuclear purity shall be measured by the DIH equivalent in the Hanford reactor. For the standard specimen size and standard. conditions of the Hanford test, the average DIH value for each graphitizing furnace lot* shall be +0.25 or greater. The samples for this measurement are described in Section VIII-B-2 of this specification.
\end{abstract}

V. MECHANTCAL PROPERTIES:

The material from which the sleeve is fabricated shall comply with the following requirements:

A. Minimum tensile strength at $70^{\circ} \mathrm{F}$ :

Parallel to axis of extrusion

$1000 \mathrm{psi}$

Perpendicular to axis of extrusion

800 psi

B. Minimum flexural strength at $70^{\circ} \mathrm{F}$ parallel

to axis of extrusion

$1800 \mathrm{psi}$

VI. DIMENSIONAL TOLERANCES:

The support sleeve shall conform dimensionally to Dwg. D-2-02-054-9812-C. A summary of the critical tolerances is presented below:

\begin{abstract}
Bore Diameter
Bore Straightness

Width of slots, top and bottom

Circumferential position of top and bottom slots
\end{abstract}

$$
\begin{aligned}
& 3.000 \pm 0.005 \text { in. } \\
& 0.020-\text { in. }- \text { max bow } \\
& 0.125+0.003 \text { in. } \\
& -0.000 \text {. }
\end{aligned}
$$

Given location with permissible angular variation of $\pm 0 \mathrm{deg}$, 5 min

VII. SURFACE FINISH AND CONDITION:

All surfaces shall have a finish of $125 \mathrm{rms}$ or better. Surfaces shall. be free of cracks, chips, holes, or other mechanical defects. All surfaces shall be free of oil, grease, dirt, or other foreign materials.

*A graphitizing furnace lot is defined as that quantity of graphite contained in the furnace at one time during the graphitization process. 
EGCR FUEL ASSEMBLY SPECIFICATION
METALLURGY DIVISION
OAK RIDGE NATIONAL LABORATORY
Spec. No. EGCR-2-3

Date: Nov. I, 1960

Page: 3 of 4

Subject: SPECIFICATION FOR GRAPHITE SUPPORT SLEEVES FOR CORE I FUEL

ASSEMBLIES FOR THE EXPERTMENTIAL GAS-COOLED REACTOR

\section{ACCEPTANCE TESTS:}

A. Nondestructive

1. Each support sleeve shall be dimensionally inspected to ensure conformance to Dwg. D-2-02-054-9812-C.

2. Each support sleeve shall be visually inspected to assure conformance to Section VII of this specification. Visual examinations shall be made under direct daylight-type fluorescent illumination of at least 100-ft candles.

3. Each support sleeve shall be weighed to verify density. The minimum acceptable weight for any sleeve is $20.82 \mathrm{lb}$. The minimum acceptable average weight for all sleeves is $21.46 \mathrm{lb}$.

4. A record of the graphitizing temperature shall be supplied by the seller for each furnace lot of graphite to determine compliance with the graphitizing temperature requirements of Section II-B of this specification.

B. Destructive

1. Tensile Tests. - A total of 24 specimens from each furnace lot of material shall be selected from different regions of the furnace for tensile tests. Tensile tests shall be performed on 12 specimens taken parallel to the direction of extrusion and on 1.2 specimens taken perpendicular to the direction of extrusion, except that no more than two pairs of specimens shall be taken from any graphitized piece in the furnace lot. Tensile tests shall be performed in accordance with ASTM Designation: C $190-58$. If the average tensile strength fails to meet the requirements of Section $V$ of this specification, the furnace lot shall, be rejected unless the selier performs sufficient additional tests to demonstrate that $95 \%$ of the pieces meet the requirements $95 \%$ of the time.

2. Flexural Tests. - A total of 24 specimens from each furnace lot of material shall be selected from different regions of the furnace for flexural tests. The flexural strength shall be determined in accordance with ASTM Designation: C $78-57$ on specimens taken parallel to the direction of extrusion. Specimens shall be selected as in Section VIII-B-I of this specification. If the average flexural strength fails to meet the requirements of Section $V$ of this specification, the furnace lot shall be rejected. 


\section{EGCR FUEL ASSEMBLY SPECTFICATION METALLURGY DIVISION \\ OAK RIDGE NATIONAL IAABORATORY}

Spec. No. EGCR-2-3

Date: Nov. 1, 1960

Page: 4 of 4

Subject: SPECIFICATION FOR GRAPHITE SUPPORT SLEEVES FOR CORE I FUEL

ASSEMBDIIES FOR THE EXPERIMENTAL GAS-COOLED REACTOR

VIII. ACCEPTANCE TESTS (continued):

3. Nuclear Properties. - The nuclear purity shall be determined in the Hanford Test Reactor equipped for these measurements. Three test specimens shall be taken from each furnace lot of graphite. Each test specimen shall be taken from a different region of the furnace.

The test specimens shall be $4.187 \pm 0.005$ in. square by 49.150 \pm 0.015 in. long. Surfaces shall have a finish of $125 \mathrm{rms}$ or better. The test pieces shall be marked with the furnace lot number and the region of the furnace from which the specimens were taken.

The DIH values shall be measured in the Hanford Reactor at no cost to the seller. Results of the measurements on specimens shall be made available to the seller within two weeks after receipt of specimens by the Hanford Operation. Failure of any of the specimens to meet the requirements of section IV-B of this specification shall cause rejection of the entire furnace Iot.

The seller shall ship the DIH specimens to Hanford in accordance with instructions from the company. All transportation costs shall be for the account of the seller.

IX. MARKING AND PACKING:

A. Each sleeve shall be marked with the furnace lot number. The size of the digits shall be approx $1 / 2$ in. $x 1 / 2$ in. $x 0.040$ in.

B. Each support sleeve shall be packed in such a manner as to prevent damage and to maintain the cleanliness of the sleeve during handing and shipment.

X. TEST REPORTS:

Four certified copies of test reports shall be furnished by the seller to the company with each shipment. The test reports shall include a certification by the seller that all requirements of this specification were met. 


\section{EGCR FUEL ASSEMBLY SPECIFICATION \\ METALLURGY DIVISTON \\ OAK RIDGE NATIONAL IABORATORY}

Spec. No. EGCR-2-4

Date: Nov. $\overline{1,1960}$

Page: 2 of 2

Subject: SPECIFICAIION FOR RECORDS TO BE KEPT ON CORE I FUEL ASSEMBLIES FOR THE EXPERTMENTAI GAS-COOLED REACTOR

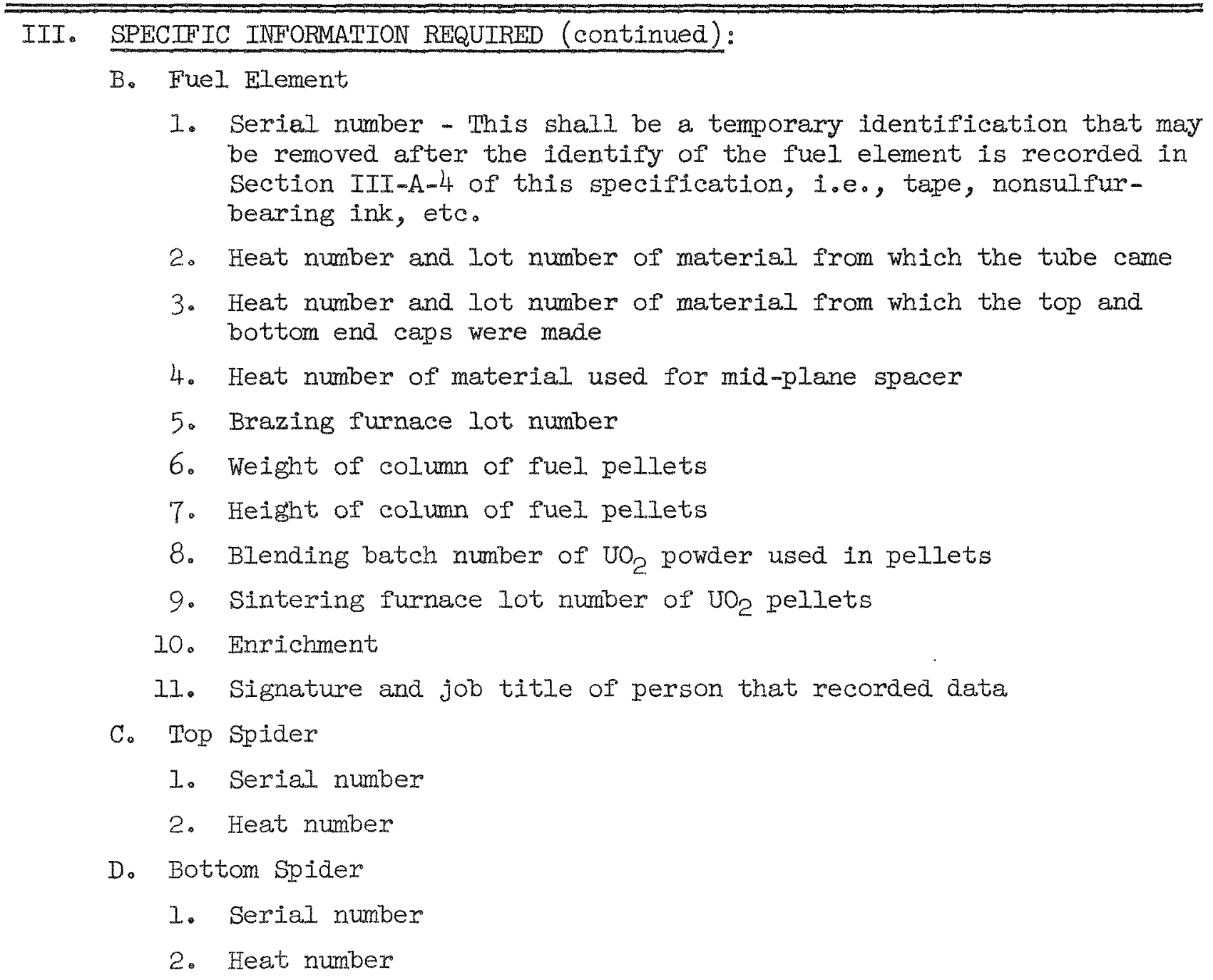


1. G. M. Adamson

2. R. J. Beaver

3. M. Bender

4. A. L. Boch

5. W. F. Boudreau

6. E. J. Breeding

7. R. B. Briggs

8. N. A. Brown

9. R. A. Charpie

10. T. E. Cole

11. J. H. Coobs

12. J. A. Conlin

13. W. B. Cottrell

14. F. I. Culler

15. H. N. Culver

16. J. E. Cunningham

17. J. H. DeVan

18. D. A. Doug:las

19. R. B. Evans

20. R. M. Evans

21. J. Foster

22. A. P. Fraas

23. J. H. Frye, Jr.

24. A. E. Goldman

25. J. M. Googin

26. B. L. Greenstreet

27. W. R. Grimes

28. J. P. Fammond

29. W. O. Harms

30. R. F. Hibbs

31. T. Hikido

32-36. M. R. Hill

37. H. Inouye

38. W. H. Jordan

39. G. W. Keilholtz

40. R. B. Korsmeyer

41. J. A. Lane

42. H. G. MacPherson

43. W. D. Manly
44. R. W. McClung

45. H. C. McCurdy

46. H, F. McDuffie

47. C. J. McHargue

48. F. R. McQuilkin

49. H. J. Metz

50. J. G. Morgan

51. F. H. Neill

52. P. Patriarca

53. A. M. Perry

54. J. T. Lamartine

55. M. W. Rosenthal

56. G. Samuels

57. H. W. Savage

58. A. W. Savolainen

59. J. L. Scott

60. 0. Sisman

61. M. J. Skinner

62. G. M. Slaughter

63. E. Storto

64. J.A. Swartout

65. A. Taboada

66. W. C. Thurber

67. G. M. Tolson

68. D. B. Trauger

69. J. R. Weir

70. E. A. Wick

71. C. E. Winters

72-86. TISE-AEC

87-90. ORNL-Y-12 Technical Library, Document Reference Section

91-93. Central Research Library

94-118. Laboratory Records Department

119. Laboratory Records Department, ORNL R.C.

120-269. Purchasing Division

270-272. W. F. Banks, Allis Chalmers

273-275. P. D. Bush, Kaiser Engineers

276. H. L. Falkenberg, IVA

277. W. R. Cooper, TVA 